Review

\title{
The Adoption of Green Vehicles in Last Mile Logistics: A Systematic Review
}

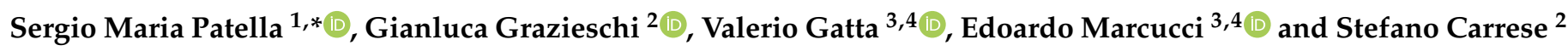 \\ 1 Faculty of Economics, Universitas Mercatorum, Piazza Mattei, 10, 00186 Rome, Italy \\ 2 Department of Engineering, Roma Tre University, Via Vito Volterra 62, 00146 Rome, Italy; \\ gianluca.grazieschi@uniroma3.it (G.G.); stefano.carrese@uniroma3.it (S.C.) \\ 3 Department of Political Science, Roma Tre University, Via Gabriello Chiabrera 199, 00145 Rome, Italy; \\ valerio.gatta@uniroma3.it (V.G.); edoardo.marcucci@uniroma3.it (E.M.) \\ 4 Department of Logistics, Molde University College, P.O. Box 2110, 6402 Molde, Norway \\ * Correspondence: sergiomaria.patella@unimercatorum.it
}

check for

updates

Citation: Patella, S.M.; Grazieschi, G.; Gatta, V.; Marcucci, E.; Carrese, S. The Adoption of Green Vehicles in Last Mile Logistics: A Systematic Review. Sustainability 2021, 13, 6. http:// dx.doi.org/10.3390/su13010006

Received: 4 December 2020

Accepted: 18 December 2020

Published: 22 December 2020

Publisher's Note: MDPI stays neutral with regard to jurisdictional claims in published maps and institutional affiliations.

Copyright: () 2020 by the authors. Licensee MDPI, Basel, Switzerland. This article is an open access article distributed under the terms and conditions of the Creative Commons Attribution (CC BY) license (https: / creativecommons.org/ licenses/by/4.0/).

\begin{abstract}
Widespread adoption of green vehicles in urban logistics may contribute to the alleviation of problems such as environmental pollution, global warming, and oil dependency. However, the current adoption of green vehicles in the last mile logistics is relatively low despite many actions taken by public authorities to overcome the negative externalities of distributing goods in cities. This paper presents a comprehensive literature review on studies investigating the adoption of green vehicles in urban freight transportation, paying specific attention to e-commerce. To shed light on the adoption of green vehicles in city logistics, the paper conducts a systematic review of the empirical literature on the topic. The 159 articles reviewed were classified into the following: (a) Optimization and scheduling (67 papers); (b) policy (55 papers); (c) sustainability (37 papers). Among the 159 articles, a further selection of 17 papers dealing with e-commerce, i.e., studies that highlight the most relevant aspects related to the integration of green vehicles in e-commerce urban logistics, was performed. Our findings indicate that green vehicles are competitive in urban deliveries characterized by frequent stop-and-go movements and low consolidation levels while incentives are still necessary for their adoption. The use of autonomous vehicles results the most promising and challenging solution for last-mile logistics.
\end{abstract}

Keywords: last mile logistics; green logistics; urban freight; e-commerce; green vehicles; drones; autonomous vehicles

\section{Introduction}

The demand for urban freight transportation has increased considerably owing to urbanization and demographic growth, along with the increased diffusion of e-commerce, new management principles (e.g., just-in-time), and the introduction of new pervasive technologies [1].

The ever-increasing trade volumes of e-commerce, which still showed a worldwide growth rate of $23.3 \%$ in 2018 and have drastically increased during the COVID-19 pandemic, have led to huge parcel volumes that need to be delivered each day especially in large urban areas. More and more delivery vehicles are required to bridge the last mile towards the customers [2].

Due to the increasing number of goods vehicle movements in urban areas, modern cities are facing congestion, lack of public space, air pollution, noise, etc., which are reducing life quality. In fact, as mentioned by Janjevic et al. [3], urban logistics operations have a considerable impact on three different aspects of sustainability: Economic (e.g., efficiency and costs of deliveries), environmental (e.g., $\mathrm{CO}_{2}$ emissions), and social (e.g., congestion).

To cope with this situation, city municipal administrations are implementing several sustainability initiatives such as urban consolidation centers, intelligent fleet management 
systems, use of green vehicles, and putting in place various freight regulations such as vehicle sizing, access timing restrictions, and congestion pricing [4-6]. The efforts made by public authorities are also in line with the goals that the EU is pursuing with respect to this sector as indicated in the white paper 2011 on transport [7] where it is stated that a reduction of at least $60 \%$ of GHGs by 2050 with respect to 1990 is required from the transport sector. Moreover, in the second point of the white paper 2011 it is affirmed that, in order to reach the energy and environmental target set, technological innovations able to raise vehicle energy efficiency are required along with the implementation of new technologies and engines for clean road transport. Among these concepts, this paper focuses on green vehicles adoption due to its relevance in a context where the increase in the e-commerce market and the rise of on-demand logistics imply poor efficiency and might cause additional negative environmental consequences.

The innovations introduced have been disruptive, especially with respect to new engine technologies and driverless vehicles [8,9]. The European Commission considers green vehicles ( $\mathrm{a}$ 'green' vehicle is defined as one with emissions intensity that does not exceed $120 \mathrm{~g}$ of $\mathrm{CO}_{2}$ emissions per $\mathrm{km}$ [10]) relevant for decarbonizing transport, reducing air pollution, and increasing system efficiency. Green vehicles such as electric vehicles $(\mathrm{EVs})$, autonomous vehicles (AVs), and drones will be evaluated in terms of their current integration in city logistics.

The paper aims at providing a literature review concerning the introduction of green vehicles in the last mile distribution to identify the main issues and challenges. Moreover, this study proposes some research directions and approaches for the advancement of sustainable freight transportation in urban logistics.

As observed by Hu et al. [11], achieving green logistics goals relies on two dominant strategies: (1) To promote the introduction of green vehicles; (2) to develop and implement policy measures and regulations to reduce the negative effect of city logistics. The research presented in this paper attempts to perform a systematic review on the first of these aspects, distinguishing from previous similar works for this specific focus. The state of the art and trends of the growing research on the integration of green vehicles in urban freight distribution are explored.

A recent review reporting a comprehensive analysis from a broad perspective of the research on green logistics has been proposed by Ren et al. [12]. They found that the number of papers published in this field has been rapidly growing in the past two years as well as the multitudinous research directions.

An integrated view of the literature published on the research area of last mile logistics, has been also proposed by Olsson et al. (2019) [13]. They report four previous systematic reviews focusing on specific elements within the area of last mile logistics [14-17]. Among these studies, only the review proposed by de Oliveira et al. [17] focused on vehicles alternatives for last mile distribution in urban freight.

In this light, the purpose of this study is to update and consolidate the current understanding with respect to the adoption of EVs, AVs, and drones in urban logistics, shedding light on the e-commerce sector.

The reminder of the paper is organized as follows. Section 2 outlines the methodology used to perform the literature review, with results presented in Section 3. Section 4 provides an overview of the most relevant aspects related to the integration of green vehicles in e-commerce urban logistics. Section 5 concludes, summarizes the paper, and provides some suggested future research paths.

\section{Methodology}

The literature selection procedure is shown in Figure 1. The keywords selected in the initial thematic search were: 'autonomous vehicles', 'electric vehicles', 'green vehicles', 'last mile logistics', 'urban logistics', 'city logistics', and 'urban freight'. The query string used for database searches was: ((«autonomous vehicles» $O R$ «electric vehicles» OR 
«green vehicles» OR «drones») AND («last mile logistics» OR «urban logistics» OR «city logistics» OR «urban freight»)).

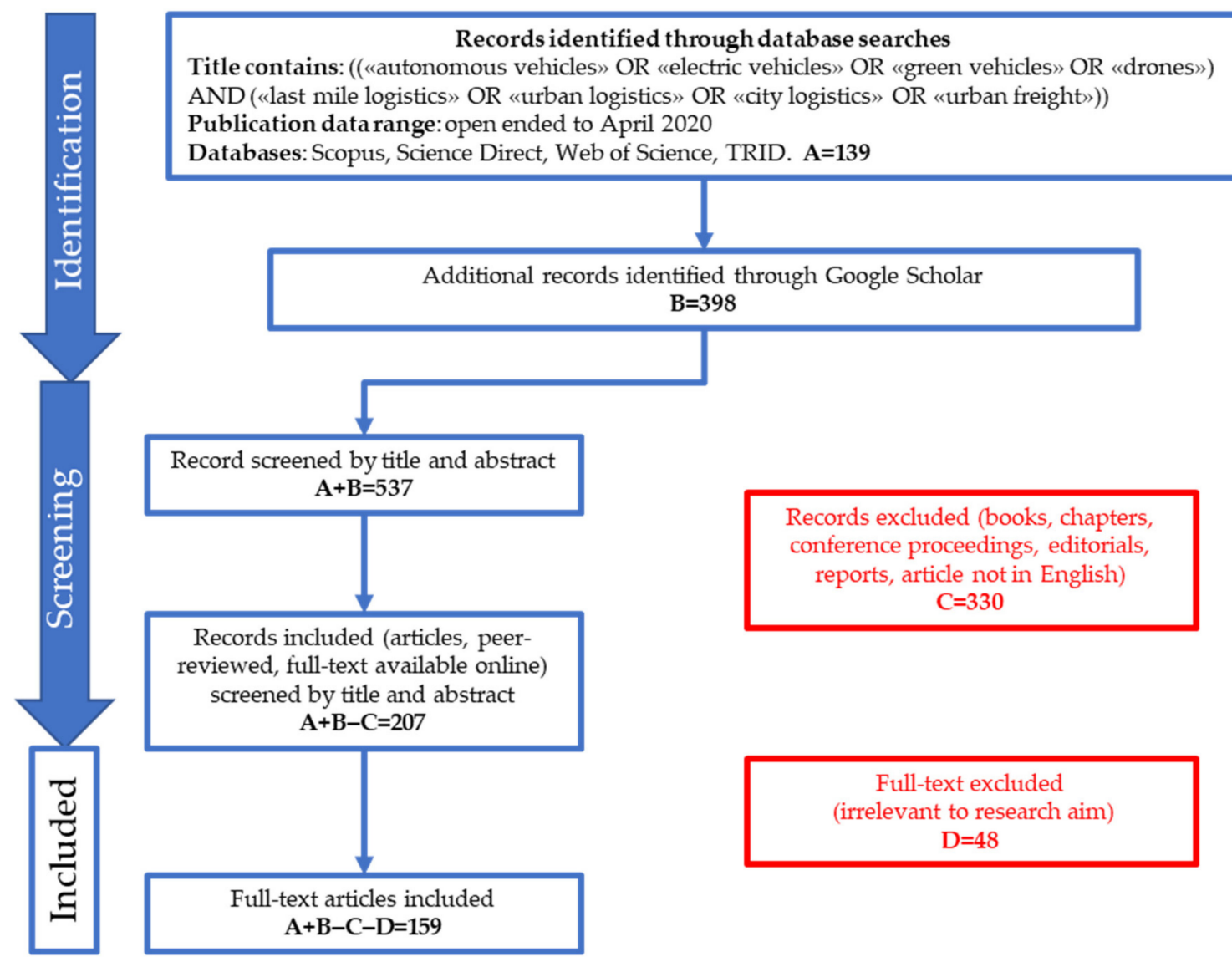

Figure 1. Procedure for literature selection.

To ensure homogeneous quality levels of the contribution investigated, we have only included papers published in peer-reviewed journals in English. Consequently, the literature review excludes sources falling outside the perimeter of peer-reviewed articles available online (e.g., conference proceedings, book chapters, and white papers) or not written in English, since this represents the dominant language in last mile logistics research (box C in Figure 1). Although some papers were selected since they matched the keywords used in the search process, after reading the abstracts we excluded 48 since the key topic was not aligned with the research focus of our paper (box D in Figure 1). As mentioned in the Introduction, the paper aims at improving the understanding of the underlying motivations with respect to green vehicles adoption in last mile logistics.

A final selection of 159 papers was included in this review. Among these articles, a further selection of 17 papers which provide significant insights into the introduction of green vehicles in urban freight distribution, are discussed in Section 4.

\section{Results}

Urban logistics is a research area that encompasses different fields ranging from engineering to transportation policy and human studies. This work proposes a systematic literature review of articles belonging to different research areas. A classification of the papers reviewed is introduced to better evaluate and discuss their added value and their potential integration in the future research directions about the diffusion of green vehicles in e-commerce and urban logistics. Three main categories were identified: Optimization and scheduling $(\mathrm{O})$, policy $(\mathrm{P})$, and sustainability $(\mathrm{S})$. A similar categorization was also 
found in other literature review papers [18,19]. The following criteria were employed for the classification of the papers.

- Optimization and scheduling: The works investigating operation research problems were included in this category. The methodologies that are generally applied are based on mixed integer mathematical problems formulated to study vehicle routing problems and solved using algorithms aiming at minimizing delivery time, total costs of the activities, or the generated emissions. Neural networks, mathematical optimization techniques, and stochastic modeling are further characteristic applications regarding this category.

- Policy: The works classified in this category focus on governance, planning, regulations, and incentives for innovative technologies. The topics are centered on:

- Evaluation of policy interventions effectiveness/acceptability before and/or after their deployment.

- Innovative incentivization schemes in order to facilitate the spread of 'green vehicles'.

- Coordination among stakeholders having contrasting interests.

- Recommendations for policy or decision makers, both public and private, aiming at improving urban logistics.

The methods that are commonly applied are based on econometric or statistical analyses of empirical data acquired via questionnaires or stakeholders' interviews.

- Sustainability: Environmental, economic, and social sustainability considerations characterize this group. The papers included usually evaluate some logistics configurations or future scenarios comparing their economic and environmental performances. Social sustainability focuses on quality of life and conflicts concerning the use of space in urban cities. The methodologies that are often applied in this section make use of life cycle analysis, energy/fuel consumption modeling, economic analysis, or performance indicators.

Some review articles [18-21], employing a multidisciplinary approach, investigated aspects belonging to different categories (e.g., policy and sustainability). In these few cases the papers were classified following the topic that was considered characteristic and prevailing. Finally, the works about e-commerce were simply retrieved verifying that the topic was adequately dealt with in the text.

Tables A1-A3 in the Appendix A summarize the classification of the main contributions of the relevant papers included in this review sorted by the number of citations; a similar approach has been already proposed by Hilmola [22]. Figure 2 plots the publication year of the works selected. It can be noted that most of the works are quite recent and belong to the 2010-2020 decade. Figure 3 shows the distribution of the works per category: $42 \%$ belongs to the optimization and scheduling group $(\mathrm{O}), 34 \%$ is related to policy $(\mathrm{P})$, and $24 \%$ is sustainability centered (S). The total percentage of papers containing references to e-commerce is $11 \%$ with $5.7 \%$ belonging to the policy group (see Figure 3). Figure 4 shows a word map colored for the number of authors per country: As can be expected, the most of them are affiliated with research institutions settled in developed countries (e.g., Europe and North America). Table 1 shows the most active authors with more than three papers in the sample analyzed. 


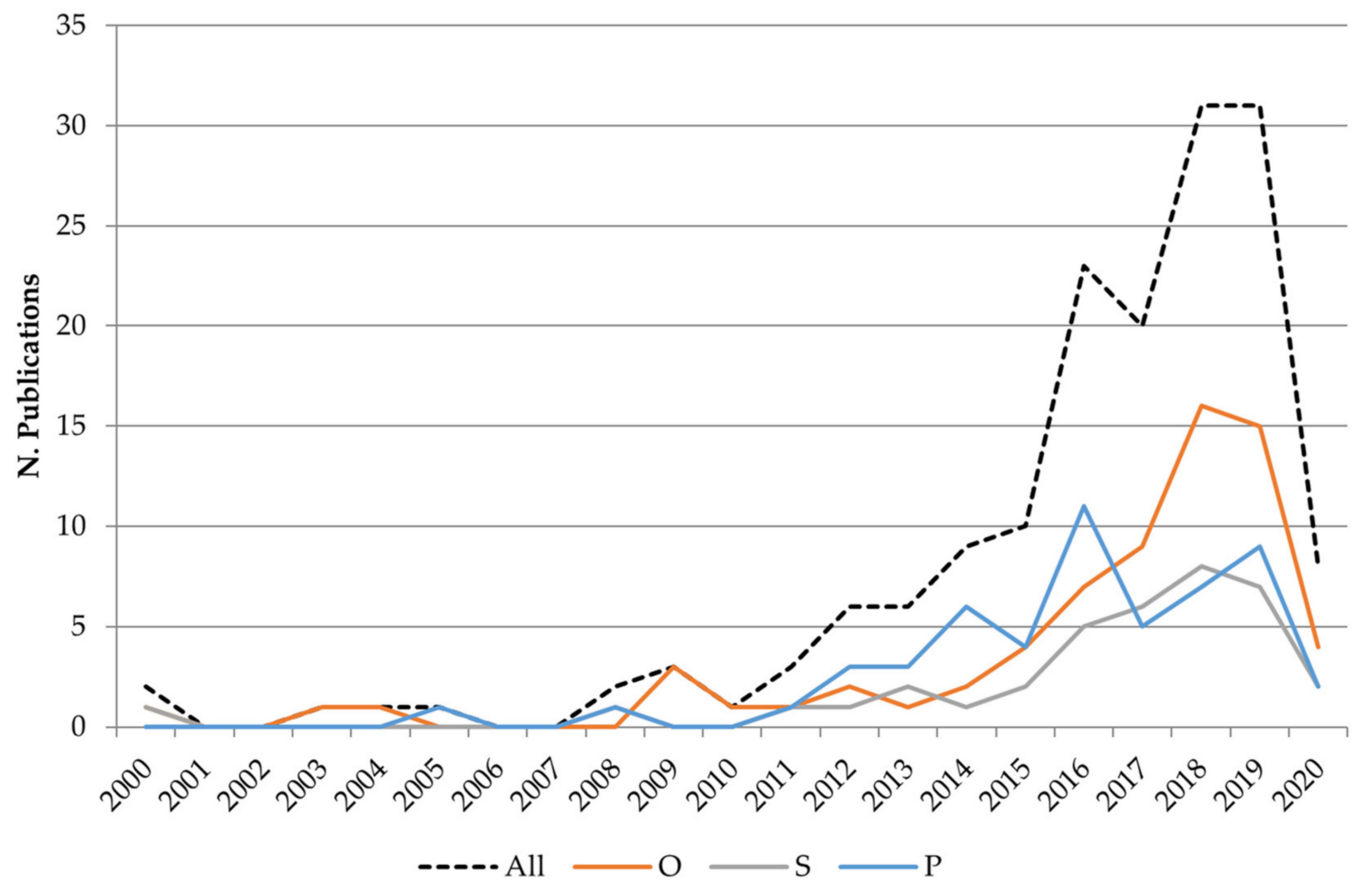

Figure 2. Number of papers considered per category and year of publication.

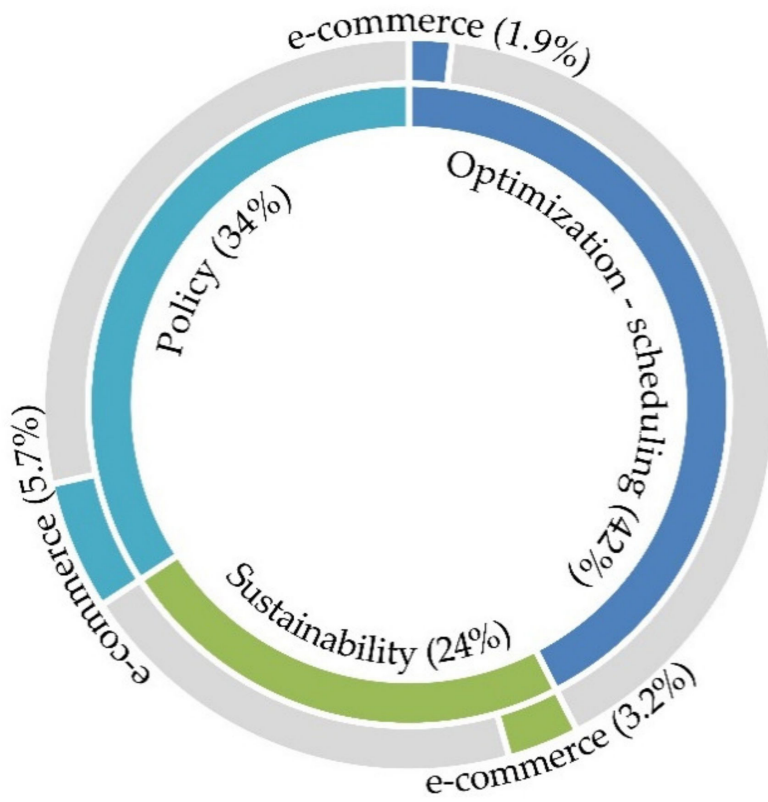

Figure 3. Representativeness of every category and of e-commerce related works. 


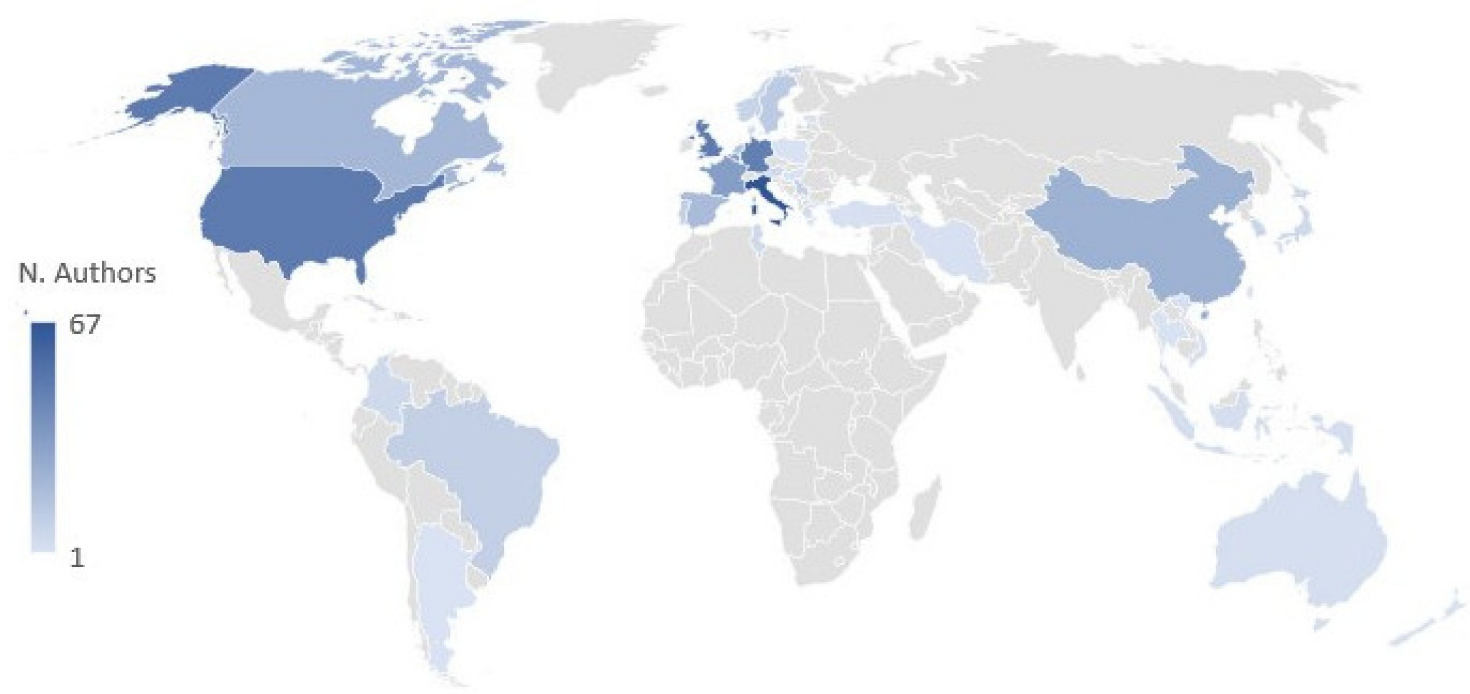

Figure 4. Colored map-number of authors per country.

Table 1. Most active authors (more than three papers) sorted by number of citations.

\begin{tabular}{cccc}
\hline Author & Institution & Number of Papers & Number of Citations \\
\hline Teodor Gabriel Crainic & CIRRELT, Montréal & 3 & 1081 \\
Maria Lindholm & Chalmers University of Technology of Göteborg & 3 & 521 \\
Fraser McLeod & University of Southampton & 4 & 336 \\
Tom Cherrett & University of Southampton & 4 & 336 \\
Julian Allen & University of Westminster of London & 3 & 286 \\
Antonio Comi & Tor Vergata University of Rome & 3 & 198 \\
Cathy Macharis & Vrije Universiteit Brussel & 7 & 156 \\
Javier Faulin & Public University of Navarre & 4 & 154 \\
Gilbert Laporte & HEC, CIRRELT Montréal & 4 & 141 \\
Joeri Van Mierlo & Vrije Universiteit Brussel & 5 & 135 \\
Philippe Lebeau & Vrije Universiteit Brussel & 5 & 135 \\
Ola Jabali & Polytechnic University of Milan & 3 & 125 \\
Samuel Pelletier & HEC, CIRRELT Montréal & 3 & 125 \\
Dirk Christian Mattfeld & University of Braunschweig & 3 & 75 \\
Tessa T. Taefi & Reutlingen University & 3 & 71 \\
Nils Boysen & Friedrich-Schiller-Universität of Jena & 3 & 68 \\
Stefan Schwerdfeger & Friedrich-Schiller-Universität Jena & 3 & 68 \\
\hline
\end{tabular}

\subsection{Optimization and Scheduling Group}

As reported in Figure 2, the academic interests in urban freight distribution from the operation research point of view is significantly increased through time. Most of the literature focus on green vehicles routing and scheduling problem (GVRSP). This aims to minimize green-house gas (GHG) emissions in logistics systems through better planning of deliveries/pickups made by a mixed fleet of vehicles (green and traditional). The optimization techniques can be applied to several aspects capable of reducing externalities in smart logistics [14]. Cattaruzza et al. [23] provide a general overview of the most relevant studies of the GVRSP for city logistics.

In the mathematical formulations of the GVRSP the charging time is considered a downtime and the insufficiency of charging infrastructure as well as the battery limitations are considered a barrier for the integration of green vehicles in urban logistics.

Many studies propose models and applications for the optimal location of charging stations for electric freight vehicles [24-26]. A recent article by Cortés-Murcia et al. [27] propose a novel variant of the electric vehicle routing problem (EVRP) where the customer 
visits are allowed by an alternative means of transport while the EV is at a recharging station.

Recent studies have proposed models for the GVRSP considering a mixed fleet of traditional manually operated vehicles and autonomous vehicles (AVs). This represents a substantial technological advance in the field of transportation [28] and is expected to play an important role in supporting the last mile logistics within intelligent transportation systems [29]. Bucsky [30] highlights that autonomous vehicles can navigate less efficiently than human driven trucks and special drop-off places should be created since parking for a longer period and lack of human communication with other drivers could generate traffic congestion in mixed fleet scenarios.

To reduce excessive road traffic from last mile deliveries, Boysen et al. [31] propose the use of unmanned aerial vehicles (also known as drones) launched from trucks. The authors provided an optimization model where the truck serves both as a mobile depot for the goods and as a mobile launching platform for one or multiple drones based on the top of the truck. The en-route launch of the drone, i.e., the drone is launched from the truck and later re-joins the truck, and its relative optimization model has been also proposed by [32-34].

Since the standard GVRSP does not allow multiple trips to the depot, Dorling et al. [35] suggests solving drone delivery problems with a multitrip vehicle routing problem to overcome the difficulties caused by the short operating ranges of drones. Other studies [36,37] are aimed at finding the best spatial distribution of facilities of launch and recharge stations for a drone delivery system.

It is worth mentioning that recent and comprehensive review on GVRSP from various perspectives can be found in Moghdani et al. [38] and Ferreira et al. [39].

\subsection{Policy}

One of the main issues regarding policy applied to urban freight logistics is to develop methods to support decision makers for the ex-ante evaluation of possible alternative solutions taking into account the interests and preferences of all different stakeholders involved $[40,41]$. The integration and coordination of the different stakeholders (public and private) is a valuable solution to improve urban freight logistics reducing costs and negative environmental externalities [42,43]. The creation of urban consolidation centers (UCCs), for example, can result in a great commitment for the stakeholders involved and the interplay among them is often characterized by conflicting objectives [44]. As observed by Cleophas et al. [45], the key challenge to developing sustainable urban logistics is collaboration between businesses, logistics service providers, citizens, and the public sector.

The horizontal and vertical collaboration among courier companies in load consolidation can provide consistent benefits for all the subjects involved [46,47] also reducing urban congestion and pollution problems. Subcontracting and partnership should be preferred over creating new on-demand dedicated services [48] that would imply a huge investment on warehouse facilities and large delivery fleets. The use of sub-contractors is particularly desirable in urban contexts with strong regulatory constraints, high flexibility, and seasonal variations of flows. The spread of cross borders parcel distribution is boosting the cooperation of different distribution actors in the use of a common information technology platform and in the establishment of cross border settlements. The awareness of political authorities about the potential of e-commerce is growing and new regulations are developing aiming at improving the convenience of the service for customers [48].

The usage of small electric vehicles for urban deliveries is incentivized by public authorities because of their capacity for local pollution reduction [49]. For this reason, electric vehicles are often free from restrictions of access to inner city centers [5]; moreover, their ease of movement through the narrow streets of historic centers facilitates the delivery processes. 


\subsection{Sustainability}

The claim for the reduction of negative externalities deriving from urban freight logistics is growing and the attention is focused on economic and environmental sustainability. This is strongly linked to the reduction of greenhouse gas emissions and other air pollutants in urban areas. The strategies that are often considered in order to improve the logistics system from both the environmental and costs perspectives are the reduction of the vehicles size and their electrification $[14,17,50]$, conversion of a homogeneous fleet to a mixed one [1,51], creation of UCCs that work in combination with a mixed fleet for deliveries [14,52-54].

A recent solution refers to the use of crowdshipping especially for last-mile deliveries, however, its impacts mostly depend on the mode employed, length of detour, parking behavior, and daily traffic variations [55]. Gatta et al. [56] investigate a green-type of crowdshipping based on public transportation, estimating its environmental and economic impacts.

The use of light electric vehicles, drones, unmanned aerial vehicles, or cargo bikes constitute a solution that can reduce the operational energy requirements in most of the cases analyzed [52,57] even if the mileage toured is higher than that characterizing traditional vans. The capacity of new delivery vehicle types is lower, and a higher number of tours are necessary to serve the same number of customers. The spread of renewable electricity production is able to further reduce operational well-to-wheel energy consumption increasing the sustainability level of the electrification of the fleets employed for last mile deliveries [58]. The reduction of the operational energy is always coupled with a reduction of some environmental impacts, such as the amount of greenhouse gas emissions.

Life cycle assessment (LCA) applications are performed by different authors [59-61] to evaluate the overall benefits when the reduction of the operational energy consumption of urban freight vehicles is followed by an increase of the use of energy storage technologies or the necessity of new urban facilities. The importance of a life cycle approach is also underlined by Taefi et al. and Patella et al. [62,63]. This article, analyzing the economic sustainability of the application of electric vehicles in urban logistics, stresses the importance of long mileages and long battery warranties as the precondition for their real competitiveness in substitution with traditional internal combustion engines. Moreover, the high cost of the battery is still a strong limit for the diffusion of electric vehicles and incentives are fundamental to guarantee their economic competitiveness $[37,64]$. Furthermore, some literature works [65-67] showed a negative correlation between the reduction of greenhouse gas emissions and the life cycle costs of the delivery system: only in some specific cases it is possible to obtain a win-win scenario.

The presence of battery charging restrictions and reduced vehicle speed cause the design of shorter routes, the increase of the total daily mileage of tours, and the multiplication of urban facility requirements (e.g., UCC, satellites, micro-consolidation centers, charging stations). Melo et al. [68] provided an example showing that cargo bikes, which have a strong potential in emission and environmental impacts reduction, need to establish an urban facility in city centers to operate adequately. The reduction of the operational energy use and of the related environmental impacts linked to the delivery vehicles causes an increase in the embodied components characterizing the supporting logistics facilities. Moreover, the increase in the number of warehouses causes an increment of the energy required for their operation. Stalaroff et al. [61] show that, in some cases, the proliferation of new urban depots and facilities can result in an increase of the overall life cycle environmental burdens so that their implementation should be carefully evaluated. The application of LCA is strongly recommended since the methodology can evaluate the right compromise between environmental impacts belonging to different life cycle phases avoiding burden shifting. Moreover, the localization of depots in the inner parts of the cities is becoming complicated and scarcely affordable because of increasing land use values [69]. The sprawl of freight facilities in the suburbs or in the external parts of the cities, where the price of land is lower, contributes to increasing the length distances of the journeys. The high 
competition for land use in the core of the cities also involves the reallocation of space for social activities, green mobility, public transport, and pedestrians. The increasing congestion on the streets is, in fact, reducing the space required for socialization due to the deterioration of the quality of livable areas. Furthermore, the absence of bike lanes and pedestrian safe paths hinders sustainable mobility and provokes road accidents [70]. Dedicated infrastructure for walking, cycling, and recreational activities are necessary in modern sustainable cities and sustainable lifestyles are demanding a reduction of the amount of space for traffic [71].

\section{The Adoption of Green Vehicles on E-Commerce City Logistics}

Different studies $[61,72,73]$ showed that e-commerce is more sustainable than retail pick-up or traditional shopping. In a life cycle perspective, Weber et al. [74] showed that e-commerce delivery systems are characterized by $30 \%$ lower primary energy consumption and $\mathrm{CO}_{2}$ emissions when considering the warehouses energy demand, energy used in retail stores and headquarters, electricity used for home computer shopping activities and data centers, fuel necessary for transportation (from manufacturer to wholesale warehouse, from the wholesale warehouse to the retail stores or distribution centers, for last mile deliveries), and packaging. The last mile delivery represents, on average, the most important contribution with respect to total $\mathrm{CO}_{2}$ emissions associated with e-commerce $(32 \%)$. The wholesale warehousing energy use represents the second contribution (31\%) of the total emissions linked to the e-commerce delivery system, but a similar share is registered also for traditional retail (26\%). The main difference between the two systems is linked to the increase of the packaging impacts in e-commerce and to the reduction of the energy necessary for customers' transport to retail stores that, in traditional retail shopping, plays a preponderant role. The significant role played by last mile delivery in the definition of the global impacts linked to e-commerce activities explains why the topic attracts such attention by the scientific literature.

One of the main characteristics of e-commerce deliveries is their small size and light weight. The former property makes the consolidation of traditional diesel vans very difficult [75] and pushes towards the reduction of the size of the vehicles used for last mile activities in response to smaller, fragmented, and more frequent deliveries. Boosted by the spread of e-commerce, the number of light goods vehicles circulating in the inner city areas is increasing more than the number of heavy goods vehicles or cars [69]. The reduction of the capacity of fleet vehicles is, however, necessary for deliveries in historic centers characterized by narrow streets. Electrification is pursued since the efficiency of electric engines at low driving speeds (about $50 \mathrm{~km} / \mathrm{h}$ [67]) is higher than that of fossil fuel-propelled engines due to regenerative braking. The diffusion of renewable energy generation can furthermore boost the competitiveness of green vehicles in last mile logistics both from an economic and environmental perspective. The drawback of the use of light weight green vehicles is the increase of the travelled distance as shown by different authors $[47,49,76]$. The higher mileages travelled by green vehicles can increase traffic congestion and its negative externalities; off-peak deliveries are suggested by different authors [49] to avoid worsening scenarios.

The possibility of choosing different delivery options is often given by online retailers with time windows that can be lower than $24 \mathrm{~h}$ (same-day delivery) [19]. Customers are demanding easy and fast deliveries and companies are experiencing a high pressure on delivery costs. The on-demand market is characterized by several independent players aiming at increasing the sales of their products and gaining market shares from their competitors also accepting to operate without covering the cost of last mile delivery operations. In order to increase online sales and meet customers' expectations, retailers guarantee 'free' delivery or offer different delivery options with a wide range of time windows. The guaranty of narrow time windows as a delivery option can furthermore stress the system reducing the possibility of demand aggregation and lowering the consolidation level of freight vehicles. The lower aggregation of demand produces an increase of the number of 
vehicles in circulation, of the distance travelled and, consequently, of the operational energy requirement and related environmental burdens [69,76]. In these cases, green vehicle or drone deliveries, replacing vans that are poorly consolidated, can play an important role in optimizing the system from both an environmental and economic perspective. However, even in case of drone usage, Dorling et al. [35] showed an inverse exponential relationship between the time limit and the total cost of the deliveries.

\section{Conclusions}

This systematic literature review showed that academic interest in the adoption of green vehicles in urban logistics has significantly increased as documented by the increasing number of publications on this topic in recent years.

This study confirmed that city logistics is intertwined with many aspects belonging to different fields related to urban planning, especially when considering sustainability. Three main categories were identified with respect to the various perspectives of the papers dealing with urban logistics: Optimization and scheduling $(\mathrm{O})$, policy $(\mathrm{P})$, and sustainability (S).

Green vehicles routing problems (GVRP), which represent the most relevant contribution of operations research to green logistics, are included in the "optimization and scheduling" category. Our analysis confirmed findings from Moghdani et al. [38], showing that the number of research studies interested in GVRP has grown rapidly.

Policy actions aiming at increasing the sustainability level of the system and the collaboration between stakeholders are discussed in the second category. The collaboration has been identified by many authors (e.g., Gatta et al. [40], Cleophas et al. [45]) as the key factor to increase urban freight sustainability.

The third category includes studies about environmental (employing LCA methodologies), economic, and social sustainability. The category subdivision resumes three different approaches developed by the literature analyzed in the study of the adoption of green vehicles in last mile logistics.

The issues connected to the rise of e-commerce are addressed by papers classified in each category identified. E-commerce is more sustainable than traditional retail shopping [61,72-74]: last mile delivery and warehouse management represent the trickiest phases but an important reduction of the environmental impacts linked to customers travelling to retail stores, that in traditional shopping are the highest, can be reached. However, the effort in market shares acquisition by independent online sellers, the guaranty of narrow delivery time windows options, and the small size of the largest part of delivered items challenge the consolidation level of traditional diesel vehicles stressing the system and increasing its negative externalities $[19,76]$ : The higher resulting number of vehicles in circulation and the higher distance travelled increase the energy use and the connected environmental burdens related to the delivery phase. In order to respond to this challenge, the adoption of green vehicles (lightweight electric vehicles, cargo bikes, unmanned aerial vehicles (UAVs), etc.) are being evaluated because of their potential to reduce the environmental burdens connected to last mile delivery, particularly in urban environments $[52,57,58,68]$. Their adoption is also incentivized by administration authorities to control local pollution [5]. The life cycle economic and environmental sustainability of the process is however still debated since the high impacts of batteries [62] and the necessity of new depots and facilities characterized by not negligible energy requirements $[61,68,77]$ contribute to worsen this scenario.

The development of vehicle technologies such as electric vehicles, connected and automated vehicles, and drones, as well as the introduction of new business models for freight transportation, requires new strategies to control the urban transportation system (freight and travelers) effectively and globally. There is a need for a system-based vision, and therefore researchers are encouraged to chart new territory in the literature by exploring ways in which overall urban transport sustainability can be enhanced. Even more important, whenever innovative solutions or disruptive changes, such as those related to the 
introduction of green vehicles, are tested and implemented, accurate behavioral analyses based on stated preference methods are needed to investigate stakeholders' acceptability and reactions.

As to the limitations of the research presented in this paper, this review is subject to the potential omission of relevant studies which have not been covered by the keywords. Moreover, the search excludes records which may potentially be relevant such as books, chapters, conference proceedings, editorials, reports, and articles not in English.

Author Contributions: Conceptualization, S.M.P. and V.G.; investigation, S.M.P. and G.G.; methodology, S.M.P. and G.G.; supervision, V.G., E.M. and S.C.; writing-original draft, S.M.P., G.G., V.G. and E.M.; writing-review and editing, S.M.P., G.G., V.G. and E.M. All authors have read and agreed to the published version of the manuscript.

Funding: This work was supported by the Roma Tre University (Research Development Plan: Action 4) research project: ShareLab-Sharing Economy in a Living Lab. Edoardo Marcucci and Valerio Gatta would like to acknowledge the funding from the European Union's Horizon 2020 research and innovation program under grant agreement No 861598 for the LEAD project (www.leadproject.eu/)

Conflicts of Interest: On behalf of all authors, the corresponding author states that there is no conflict of interest.

\section{Nomenclature}

EVs

Electric vehicles

LCA

Life cycle analysis

UCC

Urban freight consolidation center

UDC

Urban distribution center

UAV

Unmanned aerial vehicle

GVRSP

Green vehicles routing and scheduling problem 


\section{Appendix A}

Table A1. Papers included in "optimization and scheduling" category by the proposed review (sorted by citations as of June 2020).

\begin{tabular}{|c|c|c|c|c|}
\hline Reference & Pub. Year & Citations & Category & Main Topic and Findings \\
\hline Crainic et al. [78] & 2009 & 556 & $\mathrm{O}$ & $\begin{array}{l}\text { Two-echelon, synchronized, scheduled, multi-depot, multi-tour heterogeneous } \\
\text { vehicle routing problem with time window: mathematical formulation. }\end{array}$ \\
\hline Crainic et al. [79] & 2004 & 483 & $\mathrm{O}$ & Model for the optimization of freight transport in congested urban areas (e.g., Rome). \\
\hline Murray and Chu [80] & 2015 & 360 & $\mathrm{O}$ & Vehicle routing problem with a UAV working in parallel with a truck. \\
\hline Ropke and Cordeau [81] & 2009 & 351 & $\mathrm{O}$ & $\begin{array}{l}\text { Pick-up and delivery problem with time window: mathematical formulation and } \\
\text { solution methodology. }\end{array}$ \\
\hline Dorling et al. [35] & 2017 & 292 & $\mathrm{O}$ & Vehicle routing problem considering drones delivery. \\
\hline Taniguchi and Van Der Heijden [82] & 2000 & 258 & $\mathrm{O}$ & $\begin{array}{l}\text { Vehicle routing and scheduling problem with time windows combined with a } \\
\text { dynamic traffic simulation model to assess the performance of city logistics initiatives. }\end{array}$ \\
\hline Boyer et al. [83] & 2009 & 216 & $\mathrm{O}$ & Optimization of the last mile delivery: effects of density and time-windows. \\
\hline Cattaruzza et al. [23] & 2017 & 148 & $\mathrm{O}$ & Review about "Vehicle Routing Problem". \\
\hline Ha et al. [32] & 2018 & 133 & $\mathrm{O}$ & Travelling salesman problem with drones minimizing costs and delivery times. \\
\hline Ćirović et al. [84] & 2014 & 109 & $\mathrm{O}$ & $\begin{array}{l}\text { Vehicle routing problem of a mixed fleet of green and traditional vehicles. The } \\
\text { optimization is performed from an environmental and economic perspective. }\end{array}$ \\
\hline Ehmke et al. [86] & 2012 & 69 & $\mathrm{O}$ & Floating car data to optimize tour times. \\
\hline Juan et al. [87] & 2016 & 68 & $\mathrm{O}$ & Vehicle routing problem considering electric vehicle autonomy. \\
\hline Fatnassi et al. [88] & 2015 & 61 & $\mathrm{O}$ & $\begin{array}{l}\text { Transportation problem of a dynamic personal rapid transit and freight rapid } \\
\text { transit solution. }\end{array}$ \\
\hline Devari et al. [89] & 2017 & 59 & $\mathrm{O}$ & Benefits of crowdsourcing in last mile delivery. \\
\hline Gentile and Vigo [90] & 2013 & 56 & $\mathrm{O}$ & $\begin{array}{l}\text { New models to describe generation and distribution of freight movements in } \\
\text { urban areas. }\end{array}$ \\
\hline Zhou et al. [91] & 2018 & 53 & $\mathrm{O}$ & $\begin{array}{l}\text { Multi-depot two-echelon vehicle routing problem with delivery options } \\
\text { (e.g., intermediate pickup facilities). }\end{array}$ \\
\hline
\end{tabular}


Table A1. Cont.

\begin{tabular}{|c|c|c|c|c|}
\hline Reference & Pub. Year & Citations & Category & Main Topic and Findings \\
\hline Shavarani et al. [36] & 2018 & 50 & $\mathrm{O}$ & $\begin{array}{l}\text { Hierarchical facility location problem for a drone delivery system: the model } \\
\text { proposed finds the optimal number and location of launch and recharge stations } \\
\text { with the objective of minimizing the total costs of the system (cost of the facilities } \\
\text { and of the operation and maintenance of drones). }\end{array}$ \\
\hline McLeod and Cherrett [92] & 2011 & 50 & $\mathrm{O}$ & Loading bay: advance booking and control system. \\
\hline Ham [93] & 2018 & 49 & $\mathrm{O}$ & Parallel drone scheduling travelling salesman problem. \\
\hline Muñoz-Villamizar et al. [66] & 2017 & 47 & $\mathrm{O}$ & $\begin{array}{l}\text { Horizontal collaboration between carriers and use of electric vehicles in urban } \\
\text { freight transport: Vehicle routing problem optimizing delivery and environmental } \\
\text { costs. A relationship between delivery and environmental costs is drawn. }\end{array}$ \\
\hline Lebeau et al. [51] & 2015 & 46 & $\mathrm{O}$ & $\begin{array}{l}\text { Vehicle routing problem with time window: sizing of a mixed vehicle fleet } \\
\text { minimizing costs. }\end{array}$ \\
\hline Deutsch and Golany [94] & 2018 & 44 & $\mathrm{O}$ & Last mile delivery problem considering lockers. \\
\hline Awasthi et al. [4] & 2016 & 42 & $\mathrm{O}$ & Selection of collaborative partners: mathematical modeling. \\
\hline Park et al. [95] & 2016 & 42 & $\mathrm{O}$ & Vehicle routing problem considering collaborative logistics in last mile delivery. \\
\hline Tavana et al. [97] & 2017 & 38 & $\mathrm{O}$ & $\begin{array}{l}\text { Optimization of the logistics operations in cross-docks considering the use of drones } \\
\text { or of traditional vehicles. }\end{array}$ \\
\hline Schiffer and Walthera [98] & 2018 & 36 & $\mathrm{O}$ & $\begin{array}{l}\text { Location routing problem with intra-route facilities solved using an adaptive large } \\
\text { neighborhood search algorithm. }\end{array}$ \\
\hline Yu and Lam [99] & 2018 & 31 & $\mathrm{O}$ & $\begin{array}{l}\text { Optimization of routes and charging schedules of autonomous vehicles to maximize } \\
\text { the use of renewable energy. }\end{array}$ \\
\hline Boysen et al. [31] & 2018 & 30 & $\mathrm{O}$ & Vehicle routing problem with drones minimizing the delivery duration. \\
\hline Pamučar et al. [100] & 2016 & 30 & $\mathrm{O}$ & $\begin{array}{l}\text { Green-vehicles routing model implemented in a GIS platform that aims at } \\
\text { optimizing the parameters of the environment (e.g., } \mathrm{CO}, \mathrm{NOx} \text {; noise, } \mathrm{SO}_{2}, \mathrm{PM} \text { ), } \\
\text { health, use of space and logistics operating costs. }\end{array}$ \\
\hline Wang and Sheu [34] & 2019 & 29 & $\mathrm{O}$ & Capacitated vehicle routing problem considering drones. \\
\hline Jie et al. [101] & 2019 & 26 & $\mathrm{O}$ & Two-echelon capacitated vehicle routing problem with battery swapping stations. \\
\hline Behiri et al. [102] & 2018 & 25 & $\mathrm{O}$ & $\begin{array}{l}\text { Freight-rail-transport-scheduling-problem: a tool for the evaluation of the feasibility } \\
\text { in Paris. }\end{array}$ \\
\hline
\end{tabular}


Table A1. Cont.

\begin{tabular}{|c|c|c|c|c|}
\hline Reference & Pub. Year & Citations & Category & Main Topic and Findings \\
\hline Marinelli et al. [33] & 2018 & 23 & $\mathrm{O}$ & $\begin{array}{l}\text { Travelling salesman problem with drones: the truck can deliver and pick a drone up } \\
\text { not only at a node but also along a route arc. }\end{array}$ \\
\hline Chiang et al. [103] & 2019 & 21 & $\mathrm{O}$ & Mixed integer routing problem with unmanned aerial vehicles (UAV). \\
\hline Pelletier et al. [104] & 2018 & 21 & $\mathrm{O}$ & $\begin{array}{l}\text { Comprehensive mathematical model for the cost optimization of a fleet of electric } \\
\text { freight vehicles (EVs). }\end{array}$ \\
\hline Battini et al. [105] & 2014 & 21 & $\mathrm{O}$ & Optimization problem of the last mile delivery in Haiti. \\
\hline Ahani et al. [107] & 2016 & 20 & $\mathrm{O}$ & Optimization procedure for vehicles fleets used in last-mile delivery. \\
\hline Mbiadou Saleu et al. [108] & 2018 & 19 & $\mathrm{O}$ & Parallel drone scheduling travelling salesman problem. \\
\hline Baldi et al. [109] & 2019 & 16 & $\mathrm{O}$ & New packing problem with bin-dependent items profits. \\
\hline Kin et al. [110] & 2018 & 16 & $\mathrm{O}$ & Cost optimization of alternative systems for last mile delivery. \\
\hline Franceschetti et al. [111] & 2017 & 16 & $\mathrm{O}$ & $\begin{array}{l}\text { Model for the optimization of the total cost of a vehicles freight fleet considering } \\
\text { restrictions in the access of the city. }\end{array}$ \\
\hline Sopha et al. [112] & 2016 & 13 & $\mathrm{O}$ & Dynamic vehicle routing problem. \\
\hline F. Wang et al. [113] & 2019 & 12 & $\mathrm{O}$ & $\begin{array}{l}\text { Intelligent freight vehicles scheduling and management system based on crowd } \\
\text { intelligence and ride-sharing. }\end{array}$ \\
\hline Firdausiyah et al. [114] & 2019 & 12 & $\mathrm{O}$ & $\begin{array}{l}\text { Modelling the behavior of freight carriers and of an urban consolidation center } \\
\text { (UCC) operation. }\end{array}$ \\
\hline Karak and Abdelghany [115] & 2019 & 11 & $\mathrm{O}$ & Hybrid drone-vehicle routing problem. \\
\hline Pelletier et al. [116] & 2019 & 9 & $\mathrm{O}$ & Electric vehicle routing problem with energy consumption uncertainty. \\
\hline Troudi et al. [117] & 2018 & 9 & $\mathrm{O}$ & $\begin{array}{l}\text { Capacitated vehicle routing problem with time window for the sizing of a } \\
\text { drone fleet. }\end{array}$ \\
\hline Muñoz-Villamizar et al. [65] & 2019 & 7 & $\mathrm{O}$ & $\begin{array}{l}\text { Horizontal collaboration between carriers and use of electric vehicles in urban } \\
\text { freight transport: Vehicle routing problem optimizing delivery and environmental } \\
\text { costs in short and medium term. A relationship between delivery and } \\
\text { environmental costs is deployed. }\end{array}$ \\
\hline
\end{tabular}


Table A1. Cont.

\begin{tabular}{|c|c|c|c|c|}
\hline Reference & Pub. Year & Citations & Category & Main Topic and Findings \\
\hline Rezgui et al. [118] & 2019 & 6 & $\mathrm{O}$ & $\begin{array}{l}\text { Electric vehicles routing problem with time window considering modular electric } \\
\text { freight vehicles. }\end{array}$ \\
\hline Scherr et al. [119] & 2019 & 6 & $\mathrm{O}$ & $\begin{array}{l}\text { Service network design problem for a mixed fleet of motor and autonomous vehicles: } \\
\text { the model proposed aims at optimizing the size and mix of the fleet as well as the } \\
\text { routing of vehicles. }\end{array}$ \\
\hline Shavarani et al. [37] & 2019 & 6 & $\mathrm{O}$ & $\begin{array}{l}\text { Mathematical formulation of a facility location problem aiming at minimizing the } \\
\text { total costs of a drone-based delivery system concerned with refuel stations, } \\
\text { warehouses, drone procurement, and transportation. }\end{array}$ \\
\hline Bergqvist and Monios [120] & 2016 & 6 & $\mathrm{O}$ & Intermodal high capacity transport. \\
\hline Y. Li et al. [121] & 2020 & 4 & $\mathrm{O}$ & Vehicle routing problem that minimizes the cost of an urban distribution system. \\
\hline Moeini and Salewski [122] & 2020 & 2 & $\mathrm{O}$ & Solution of the truck-drone-autonomous vehicles routing problem. \\
\hline Cortés-Murcia et al. [27] & 2019 & 2 & $\mathrm{O}$ & $\begin{array}{l}\text { Electric vehicles routing problem with time window considering the possibility of } \\
\text { costumers' self-collection during the charging process. }\end{array}$ \\
\hline H. Li et al. [123] & 2020 & - & $\mathrm{O}$ & $\begin{array}{l}\text { The two-echelon city logistics system with on-street satellites: mathematical } \\
\text { formulation and solution. }\end{array}$ \\
\hline Pinto et al. [26] & 2019 & - & $\mathrm{O}$ & $\begin{array}{l}\text { Optimization model addressing the design problem of a network of } \\
\text { charging stations to support a meal delivery service using drones. }\end{array}$ \\
\hline $\mathrm{Yu}[29]$ & 2019 & - & $\mathrm{O}$ & $\begin{array}{l}\text { Optimization in the routing and charging schedules for an autonomous vehicles } \\
\text { logistics system using distributed renewable energy generation. }\end{array}$ \\
\hline Fikar et al. [124] & 2018 & - & $\mathrm{O}$ & $\begin{array}{l}\text { Model optimizing the interaction between a traditional logistics operator and a } \\
\text { group of freelancers using cargo bikes. }\end{array}$ \\
\hline Chen [125] & 2017 & - & $\mathrm{O}$ & Model for the site selection of logistics center in an e-commerce network environment. \\
\hline Cavadas et al. [24] & 2015 & - & $\mathrm{O}$ & Mathematical model to locate charging stations for electric freight vehicles. \\
\hline Ehmke and Mattfeld [126] & 2010 & - & $\mathrm{O}$ & Time dependent optimization: management of big data about traffic. \\
\hline Dekker et al. [127] & 2012 & 734 & S & Operational research emphasis on environmental problems. \\
\hline Browne et al. [52] & 2011 & 205 & S & $\begin{array}{l}\text { Evaluation of the impacts (travelled distances, emissions, costs) of the creation of a } \\
\text { UCC in central London that employs cargo bikes and electric vehicles for the deliveries. }\end{array}$ \\
\hline
\end{tabular}


Table A2. Papers included in "sustainability" category by the proposed review (sorted by citations as of June 2020).

\begin{tabular}{|c|c|c|c|c|}
\hline Reference & Pub. Year & Citations & Category & Main Topic and Findings \\
\hline Behrends et al. [128] & 2008 & 178 & S & $\begin{array}{l}\text { Definition of a new indicator able to describe the level of sustainability in urban freight } \\
\text { transport (SUFT). }\end{array}$ \\
\hline Boerkamps et al. [54] & 2000 & 143 & S & $\begin{array}{l}\text { Model for the evaluation of the logical and environmental performances of three types } \\
\text { of urban distribution systems: the traditional system and two concepts using urban } \\
\text { distribution centers (one using vans, the other using automated underground vehicles). }\end{array}$ \\
\hline Goodchild and Toy [77] & 2018 & 96 & S & $\begin{array}{l}\text { Comparison of the emissions reduction potential of two delivery modes: one using UAV } \\
\text { and the other using trucks. }\end{array}$ \\
\hline Stolaroff et al. [61] & 2018 & 82 & S & $\begin{array}{l}\text { LCA of an urban logistics system employing UAV: drones consume less energy per } \\
\text { package-km than delivery trucks but the additional energy for warehouse requirements } \\
\text { and the longer distances per package travelled greatly increase the life-cycle impacts. } \\
\text { Small drones are more environmentally friendly. }\end{array}$ \\
\hline Arvidsson [129] & 2013 & 69 & S & $\begin{array}{l}\text { Sustainability paradox: access restrictions in city centers might increase social } \\
\text { sustainability aspects while decreasing economic sustainability. The use of multiple key } \\
\text { performance indicators in urban freight distribution is recommended. }\end{array}$ \\
\hline Brown and Guiffrida [73] & 2014 & 68 & S & $\begin{array}{l}\text { Comparison of the environmental impacts of traditional shopping and } \\
\text { e-commerce activities. }\end{array}$ \\
\hline Russo and Comi [130] & 2016 & 63 & S & $\begin{array}{l}\text { Regressive model for the evaluation of the reduction potential of the environmental } \\
\text { impacts }\left(\mathrm{CO}, \mathrm{NO}_{\mathrm{x}}, \mathrm{SO}_{\mathrm{x}}, \mathrm{PM}\right) \text { resulting from the implementation of some sustainable } \\
\text { measures in urban logistics. }\end{array}$ \\
\hline Melo and Baptista [68] & 2017 & 47 & S & $\begin{array}{l}\text { The use of electric cargo bikes is a sustainable option for last mile delivery: when } \\
\text { replacing all the conventional vans, the well-to-wheel } \mathrm{CO}_{2} \text { emission saving is } 73 \% \text {. }\end{array}$ \\
\hline Aditjandra et al. [131] & 2016 & 38 & S & $\begin{array}{l}\text { Environmental impacts }\left(\mathrm{CO}_{2}, \mathrm{PM} \text {, and } \mathrm{NO}_{\mathrm{x}}\right) \text { of heavy and light freight vehicles } \\
\text { operating in urban areas. }\end{array}$ \\
\hline Lebeau et al. [132] & 2015 & 36 & S & Total cost of ownership analysis of electric light vehicles for city logistics. \\
\hline Schöder et al. [49] & 2016 & 33 & $\mathrm{~S}$ & Impact of e-commerce on urban logistics sustainability. \\
\hline de Oliveira et al. [17] & 2017 & 32 & S & $\begin{array}{l}\text { Review about literature on sustainable vehicles for last mile delivery. A trend supporting } \\
\text { smaller and lighter electric vehicles for last mile deliveries in urban areas is discovered. }\end{array}$ \\
\hline
\end{tabular}


Table A2. Cont.

\begin{tabular}{|c|c|c|c|c|}
\hline Reference & Pub. Year & Citations & Category & Main Topic and Findings \\
\hline Faccio and Gamberi [53] & 2015 & 32 & S & $\begin{array}{l}\text { Evaluation, based on field data, of the economic and environmental sustainability } \\
\text { deriving from the creation of a centralised platform using electric vehicles to cover the } \\
\text { last } 50 \text { miles of distribution. }\end{array}$ \\
\hline Figliozzi [59] & 2017 & 32 & $S$ & LCA of a drone. \\
\hline Duarte et al. [57] & 2016 & 29 & S & $\begin{array}{l}\text { Data analysis about the energy consumptions and environmental impacts of electric } \\
\text { vehicles used for last mile logistics in Lisbon. }\end{array}$ \\
\hline Giordano et al. [58] & 2018 & 21 & S & $\begin{array}{l}\text { Comparison of diesel and battery electric delivery vans using emission and costs LCA. If } \\
\text { electricity is clean and diesel vans are old, high savings can be reached in both fields } \\
\text { from their substitution with electric ones (e.g., }-93 / 98 \% \text { of GHGs). }\end{array}$ \\
\hline Park et al. [133] & 2018 & 19 & S & $\begin{array}{l}\text { Comparison of the LCA impacts of a motorcycle delivery and of a drone delivery in } \\
\text { urban and rural areas. }\end{array}$ \\
\hline J. Wang et al. [67] & 2019 & 18 & $S$ & $\begin{array}{l}\text { A negative correlation between the cost and carbon emissions under the shortest } \\
\text { distribution routes is found. The optimized solution that minimizes the emissions of } \\
\text { greenhouse gases and the overall operational cost is searched. }\end{array}$ \\
\hline Durand et al. [134] & 2013 & 17 & S & $\begin{array}{l}\text { Comparison of the environmental and cost performances of three scenarios for } \\
\text { delivering to urban online shoppers. }\end{array}$ \\
\hline Taefi et al. [62] & 2017 & 14 & $S$ & $\begin{array}{l}\text { A high mileage increases the cost-effectiveness of medium-duty electric vehicles. } \\
\text { However, expensive battery replacements or quick charging can reduce the benefits } \\
\text { significantly. }\end{array}$ \\
\hline Aurambout et al. [135] & 2019 & 12 & S & $\begin{array}{l}\text { Market potential and economic sustainability of using drones in last mile delivery } \\
\text { within EU-28 countries. }\end{array}$ \\
\hline de Mello Bandeira et al. [50] & 2019 & 10 & S & $\begin{array}{l}\text { Sustainability assessment of electric light vehicles in the last mile of transportation and } \\
\text { of postal deliveries in Rio de Janeiro. }\end{array}$ \\
\hline Teoh et al. [136] & 2018 & 10 & $S$ & $\begin{array}{l}\text { The opportunity charging can significantly reduce the life cycle cost and emission of EVs } \\
\text { used for urban freight transport operations. }\end{array}$ \\
\hline Taefi [63] & 2016 & 8 & S & $\begin{array}{l}\text { Potential of double-shift usage in reducing the total costs of ownership of electric } \\
\text { vehicles: EVs are competitive for high daily mileages. }\end{array}$ \\
\hline Koiwanit [72] & 2018 & 7 & $S$ & LCA of drone delivery on an online shopping system. \\
\hline Semanjski and Gautama [137] & 2019 & 6 & S & $\begin{array}{l}\text { Multi-criteria decision-making approach to achieve consensus among stakeholders on } \\
\text { the best routing option from a sustainability perspective. }\end{array}$ \\
\hline Digiesi et al. [138] & 2017 & 5 & S & Review work about the strategies for the reduction of externalities in last mile logistics. \\
\hline
\end{tabular}


Table A2. Cont.

\begin{tabular}{|c|c|c|c|c|}
\hline Reference & Pub. Year & Citations & Category & Main Topic and Findings \\
\hline Figliozzi et al. [60] & 2020 & 5 & $\mathrm{~S}$ & Life cycle carbon emissions of an urban distribution centers. \\
\hline Nenni et al. [20] & 2019 & 5 & $\mathrm{~S}$ & $\begin{array}{l}\text { Sustainability-based review of urban freight models: impacts related to economic } \\
\text { (freight transport, infrastructure, employment), social (safety, security, noise) and } \\
\text { environmental (land use, energy and emissions) fields are considered. }\end{array}$ \\
\hline Bucsky [30] & 2018 & 2 & S & $\begin{array}{l}\text { Review of data about the economic and environmental sustainability concerning the use } \\
\text { of autonomous vehicles for urban freight delivery. }\end{array}$ \\
\hline Lebeau et al. [139] & 2019 & 1 & $\mathrm{~S}$ & Total cost of ownership of electric freight vehicles. \\
\hline Marmiroli et al. [140] & 2020 & 1 & $\mathrm{~S}$ & $\begin{array}{l}\text { Comparative life cycle assessment of electric, compressed natural gas and diesel } \\
\text { light-duty vehicles. Electric motors are more efficient in urban environments and the } \\
\text { role of the batteries in embodied impacts is dominant. }\end{array}$ \\
\hline Cárdenas et al. [141] & 2017 & - & $\mathrm{S}$ & $\begin{array}{l}\text { Analysis about the spatial distribution of e-commerce deliveries in Belgium and } \\
\text { definition of an external cost index per parcel delivered that considers the costs of } \\
\text { congestion, accidents, noise, air pollution and climate change. Average costs per parcel } \\
\text { are higher for deliveries in rural areas. }\end{array}$ \\
\hline Moore [142] & 2019 & - & $S$ & $\begin{array}{l}\text { Innovative scenarios for intra-city freight delivery are considered and compared with a } \\
\text { baseline scenario (diesel based) from an energy consumption perspective. }\end{array}$ \\
\hline
\end{tabular}

Table A3. Papers included in "policy" category by the proposed review (sorted by citations as of June 2020).

\begin{tabular}{|c|c|c|c|c|}
\hline Reference & Pub. Year & Citations & Category & Main Topic and Findings \\
\hline Fagnant and Kockelman [143] & 2015 & 1451 & $\mathrm{P}$ & Autonomous vehicle in the USA: advantages barriers and policy recommendations. \\
\hline Muñuzuri et al. [5] & 2005 & 373 & $\mathrm{P}$ & $\begin{array}{l}\text { Evaluation of the solutions or initiatives that can be implemented by local } \\
\text { administrations in order to improve freight deliveries in urban environments and } \\
\text { expected effects. }\end{array}$ \\
\hline Savelsbergh and Van Woensel [47] & 2016 & 265 & $\mathrm{P}$ & Challenges and opportunities in city logistics. \\
\hline Cherrett et al. [144] & 2012 & 196 & $\mathrm{P}$ & $\begin{array}{l}\text { Review article about data and information on urban freight transports. A central } \\
\text { coordination of some activities, such as service provision, can reduce } \\
\text { environmental impacts. }\end{array}$ \\
\hline Lindholm and Behrends [145] & 2012 & 191 & $\mathrm{P}$ & $\begin{array}{l}\text { Integration between public and private actors to face the sustainability challenges } \\
\text { raised by urban freight transport in Baltic countries. }\end{array}$ \\
\hline
\end{tabular}


Table A3. Cont.

\begin{tabular}{|c|c|c|c|c|}
\hline Reference & Pub. Year & Citations & Category & Main Topic and Findings \\
\hline Tadić et al. [146] & 2014 & 170 & $\mathrm{P}$ & $\begin{array}{l}\text { A multi-criteria decision-making model is proposed for the selection of the city } \\
\text { logistics concept which would be most appropriate for different participants, } \\
\text { stakeholders, and attributes of the surroundings. }\end{array}$ \\
\hline Schliwa et al. [147] & 2015 & 158 & $\mathrm{P}$ & $\begin{array}{l}\text { The local authorities play a key role } \\
\text { in creating the conditions that incentivize large logistics companies to integrate } \\
\text { cargo cycles into their supply chains. }\end{array}$ \\
\hline Marcucci and Danielis [148] & 2008 & 153 & $\mathrm{P}$ & $\begin{array}{l}\text { Stated-preference study about the potential use of an urban freight consolidation } \\
\text { center in Fano (Italy). }\end{array}$ \\
\hline Ballantyne et al. [149] & 2013 & 152 & $\mathrm{P}$ & $\begin{array}{l}\text { The work aims at demonstrating } \\
\text { that urban freight transport planning can be improved only by involving a wider } \\
\text { range of stakeholders. }\end{array}$ \\
\hline Guerra [150] & 2016 & 150 & $\mathrm{P}$ & $\begin{array}{l}\text { Policy recommendations for planning the diffusion of autonomous vehicles in urban } \\
\text { environments. }\end{array}$ \\
\hline Muñuzuri et al. [151] & 2012 & 144 & $\mathrm{P}$ & $\begin{array}{l}\text { Typical regulation schemes in Spain and reason of their obsolescence and lack of } \\
\text { enforcement. Possible efforts towards improvement are discussed. }\end{array}$ \\
\hline Gruber et al. [152] & 2014 & 102 & $\mathrm{P}$ & $\begin{array}{l}\text { Electric cargo bikes: potential market, organization of the current market, how they } \\
\text { are perceived by bike and car messengers, and what factors drive their willingness } \\
\text { to use them. }\end{array}$ \\
\hline Pelletier at al. [21] & 2016 & 95 & $\mathrm{P}$ & $\begin{array}{l}\text { Review article about goods distribution with electric vehicles: the technological and } \\
\text { market background are addressed. }\end{array}$ \\
\hline Russo and Comi [153] & 2011 & 89 & $\mathrm{P}$ & $\begin{array}{l}\text { Model that aims at supporting the ex-ante assessment of city logistics measures } \\
\text { simulating the choices of each decision-maker involved in response to } \\
\text { policy measures. }\end{array}$ \\
\hline Ducret [48] & 2014 & 86 & $\mathrm{P}$ & $\begin{array}{l}\text { Analysis of the changes in European courier, express and parcel sector: the rise of } \\
\text { cross-border e-commerce. }\end{array}$ \\
\hline Morganti and Gonzalez-Feliu [154] & 2015 & 79 & $\mathrm{P}$ & $\begin{array}{l}\text { The case study of the urban distribution center of Parma (Food Hub): the role of } \\
\text { public actors in defining adequate policy measures. }\end{array}$ \\
\hline Taniguchi et al. [76] & 2003 & 74 & $\mathrm{P}$ & $\begin{array}{l}\text { Mathematical computer-based models for the planning of city logistics schemes and } \\
\text { predicting their effects. }\end{array}$ \\
\hline
\end{tabular}


Table A3. Cont.

\begin{tabular}{|c|c|c|c|c|}
\hline Reference & Pub. Year & Citations & Category & Main Topic and Findings \\
\hline Allen et al. [69] & 2018 & 66 & $\mathrm{P}$ & $\begin{array}{l}\text { Challenges of e-commerce delivery and initiatives that retailers, parcel carriers, and } \\
\text { city authorities, can implement to reduce the costs associated with last mile logistics. }\end{array}$ \\
\hline Ajanovic and Haas [155] & 2016 & 66 & $\mathrm{P}$ & $\begin{array}{l}\text { Identify the major impact factors for a broader dissemination of EVs in urban areas. } \\
\text { The incentives should depend on the decarbonization potential of } \\
\text { electricity generation. }\end{array}$ \\
\hline Lenz and Riehle [156] & 2013 & 61 & $\mathrm{P}$ & $\begin{array}{l}\text { European experiences of cargo bike usage for delivery in cities. The spread is } \\
\text { possible only if public authorities play an important role in the promotion } \\
\text { (incentives, provision of space for depots in city centers, dedicated infrastructures). }\end{array}$ \\
\hline Roumboutsos et al. [157] & 2014 & 59 & $\mathrm{P}$ & $\begin{array}{l}\text { Definition of a methodology based on the Systems of Innovation approach to } \\
\text { examine the process by which EVs may be introduced in city logistics. }\end{array}$ \\
\hline Taefi et al. [158] & 2016 & 49 & $\mathrm{P}$ & $\begin{array}{l}\text { Multi-criteria analysis of policy measures in Germany that support the adoption of } \\
\text { electric vehicles in urban road freight transport. }\end{array}$ \\
\hline Anand et al. [159] & 2014 & 48 & $\mathrm{P}$ & $\begin{array}{l}\text { An ontology model of city logistics is proposed which includes independent city } \\
\text { logistics entities and the relationships between them in a structured form. }\end{array}$ \\
\hline Nuzzolo et al. [160] & 2016 & 46 & $\mathrm{P}$ & $\begin{array}{l}\text { Comparison of the characteristics of urban freight transport and of the logistics } \\
\text { measures being implemented in Rome, Barcelona, and Santander. }\end{array}$ \\
\hline Bjerkan et al. [161] & 2014 & 43 & $\mathrm{P}$ & $\begin{array}{l}\text { Collaborative approach in urban freight transport: stakeholder evaluations about the } \\
\text { implementation of a mobile depot and night and evening deliveries. }\end{array}$ \\
\hline Yuen et al. [162] & 2018 & 41 & $\mathrm{P}$ & $\begin{array}{l}\text { Analysis on the customers' intention to use self-collection as a last mile delivery } \\
\text { method and how to increase it. }\end{array}$ \\
\hline Lebeau et al. [163] & 2016 & 41 & $\mathrm{P}$ & $\begin{array}{l}\text { Vehicle choice behavior of transport companies and expectations: authorities should } \\
\text { encourage the use of battery electric vehicles. }\end{array}$ \\
\hline Harrington et al. [164] & 2016 & 37 & $\mathrm{P}$ & $\begin{array}{l}\text { Multi-stakeholder conceptual framework: socio-economic common interests, } \\
\text { trade-offs, and interdependences. }\end{array}$ \\
\hline Jaller et al. [165] & 2015 & 31 & $\mathrm{P}$ & $\begin{array}{l}\text { Logistics initiatives to alleviate the externalities of the freight traffic produced and } \\
\text { attracted by large freight traffic generators. }\end{array}$ \\
\hline Morganti and Browne [166] & 2018 & 30 & $\mathrm{P}$ & $\begin{array}{l}\text { Technical and operational obstacles to the adoption of electric vans in France and the } \\
\text { UK. Some financial and non-financial } \\
\text { incentives to foster the adoption of electric vans. }\end{array}$ \\
\hline Perboli and Rosano [1] & 2019 & 26 & $\mathrm{P}$ & $\begin{array}{l}\text { Harmonization of the business and operational models of traditional and green } \\
\text { logistics (mainly cycled) actors. }\end{array}$ \\
\hline
\end{tabular}


Table A3. Cont.

\begin{tabular}{|c|c|c|c|c|}
\hline Reference & Pub. Year & Citations & Category & Main Topic and Findings \\
\hline Allen et al. [46] & 2017 & 24 & $\mathrm{P}$ & $\begin{array}{l}\text { A "freight traffic controller" is proposed to manage the repartition of work between } \\
\text { parcel carriers collaborating horizontally to reduce urban congestion. }\end{array}$ \\
\hline Kane and Whitehead [168] & 2017 & 23 & $\mathrm{P}$ & $\begin{array}{l}\text { Policy actions to manage the on-going transport disruptions avoiding } \\
\text { non-optimal outcomes. }\end{array}$ \\
\hline Musolino et al. [169] & 2019 & 22 & $\mathrm{P}$ & $\begin{array}{l}\text { Methodology for the evaluation of an urban distribution center location in order to } \\
\text { pursue sustainability goals. }\end{array}$ \\
\hline Ville et al. [44] & 2013 & 22 & $\mathrm{P}$ & $\begin{array}{l}\text { The case study of the UCC of Vicenza: limits of the public policy intervention in } \\
\text { restricting vehicle access to the city center. }\end{array}$ \\
\hline Dolati Neghabadi et al. [19] & 2019 & 20 & $\mathrm{P}$ & $\begin{array}{l}\text { Systematic literature review about policy, innovative solutions, stakeholders, and } \\
\text { sustainability aspects in city logistics. }\end{array}$ \\
\hline Arvidsson et al. [170] & 2016 & 15 & $\mathrm{P}$ & $\begin{array}{l}\text { The integration of passenger and freight transport in urban areas is a promising } \\
\text { approach to ease the last mile problem. }\end{array}$ \\
\hline De Marco et al. [75] & 2018 & 14 & $\mathrm{P}$ & $\begin{array}{l}\text { Empirical analysis of a dataset about implemented city logistics measures: pollution, } \\
\text { diffusion of e-commerce and gross domestic product are important drivers of city } \\
\text { logistics deployment. }\end{array}$ \\
\hline Hoffmann and Prause [172] & 2018 & 13 & $\mathrm{P}$ & $\begin{array}{l}\text { Necessity of a clear regulatory framework for the usage of autonomous vehicles in } \\
\text { last mile delivery. }\end{array}$ \\
\hline Cagliano et al. [173] & 2017 & 13 & $\mathrm{P}$ & $\begin{array}{l}\text { Public intervention is necessary to speed the diffusion of EVs: definition of an } \\
\text { incentive scheme and evaluation of their effects. }\end{array}$ \\
\hline Lebeau et al. [174] & 2018 & 11 & $\mathrm{P}$ & $\begin{array}{l}\text { Multi-criteria analysis to support administrations in choosing, involving } \\
\text { stakeholders, the priority policy to be implemented in order to improve the } \\
\text { sustainability of city logistics. }\end{array}$ \\
\hline Christensen et al. [175] & 2017 & 10 & $\mathrm{P}$ & $\begin{array}{l}\text { Commercial sectors suitable for a shift to electric mobility: construction, human } \\
\text { health, and other service sectors. }\end{array}$ \\
\hline Kellermann et al. [176] & 2020 & 6 & $\mathrm{P}$ & $\begin{array}{l}\text { Review about the use of drones for parcel and passenger transportation: technical } \\
\text { and regulatory problems and barriers. }\end{array}$ \\
\hline Buldeo Rai et al. [177] & 2019 & 5 & $\mathrm{P}$ & $\begin{array}{l}\text { Local authorities can facilitate the adoption of emerging measures to optimize the } \\
\text { activities of logistics by cooperating with the private sector and by developing a } \\
\text { harmonized, long-term vision on freight transport policy across cities and regions. }\end{array}$ \\
\hline
\end{tabular}


Table A3. Cont.

\begin{tabular}{|c|c|c|c|c|}
\hline Reference & Pub. Year & Citations & Category & Main Topic and Findings \\
\hline Hu et al. [178] & 2020 & 4 & $\mathrm{P}$ & $\begin{array}{l}\text { Integration of freight logistics into urban passengers' rail transit network: } \\
\text { stakeholders' characterization, variables affecting the system operations and } \\
\text { external impacts. }\end{array}$ \\
\hline Matusiewicz [179] & 2019 & 3 & $\mathrm{P}$ & $\begin{array}{l}\text { Identify the conditions for the implementation of deliveries in the limited } \\
\text { accessibility zone in Gdansk and the guidelines for the implementation of a new } \\
\text { sustainable transport policy. }\end{array}$ \\
\hline Skiver [180] & 2017 & 3 & $\mathrm{P}$ & $\begin{array}{l}\text { Competition between brick-and-mortar retailers and e-commerce in guaranteeing } \\
\text { the same-day home deliveries. }\end{array}$ \\
\hline Arroyo et al. [181] & 2019 & 2 & $\mathrm{P}$ & $\begin{array}{l}\text { The effectiveness of carbon pricing policies for promoting urban freight } \\
\text { electrification in Madrid is low in the short term. }\end{array}$ \\
\hline Monios and Bergqvist [182] & 2019 & 2 & $\mathrm{P}$ & $\begin{array}{l}\text { Description of the transport geography of electric and autonomous vehicles for road } \\
\text { freight transport and identification of the many unresolved issues about to emerge. }\end{array}$ \\
\hline Ehrler et al. [183] & 2019 & - & $\mathrm{P}$ & $\begin{array}{l}\text { Perspectives, prerequisites, and challenges for a shift to electric vehicles in the last } \\
\text { mile logistics of grocery e-commerce. }\end{array}$ \\
\hline Ørving et al. [184] & 2019 & - & $\mathrm{P}$ & $\begin{array}{l}\text { Public-private partnership to facilitate the development of commercial cargo bike } \\
\text { use in Oslo. }\end{array}$ \\
\hline Cheng and Liu [185] & 2016 & - & $\mathrm{P}$ & Government policies aiming at the diffusion of EVs. \\
\hline
\end{tabular}




\section{References}

1. Perboli, G.; Rosano, M. Parcel delivery in urban areas: Opportunities and threats for the mix of traditional and green business models. Transp. Res. Part C Emerg. Technol. 2019, 99, 19-36. [CrossRef]

2. Schwerdfeger, S.; Boysen, N. Optimizing the changing locations of mobile parcel lockers in last-mile distribution. Eur. J. Oper. Res. 2020, 285, 1077-1094. [CrossRef]

3. Janjevic, M.; Knoppen, D.; Winkenbach, M. Integrated decision-making framework for urban freight logistics policy-making. Transp. Res. Part D Transp. Environ. 2019, 72, 333-357. [CrossRef]

4. Awasthi, A.; Adetiloye, T.; Crainic, T.G. Collaboration partner selection for city logistics planning under municipal freight regulations. Appl. Math. Model. 2016, 40, 510-525. [CrossRef]

5. Muñuzuri, J.; Larrañeta, J.; Onieva, L.; Cortés, P. Solutions applicable by local administrations for urban logistics improvement. Cities 2005, 22, 15-28. [CrossRef]

6. Center of Excellence for Sustainable Urban Freight Systems Improving Freight System Performance in Metropolitan Areas: Planning Guide. Available online: https:/ / coe-sufs.org/wordpress/ncfrp33/ (accessed on 17 July 2020).

7. Directorate-General for Mobility and Transport (European Commission). White Paper on Transport; European Union: Brussels, Belgium, 2011; ISBN 978-92-79-18270-9.

8. Asghari, M.; Mirzapour Al-e-hashem, S.M.J. Green vehicle routing problem: A state-of-the-art review. Int. J. Prod. Econ. 2021, 231, 107899. [CrossRef]

9. Macrina, G.; Di Puglia Pugliese, L.; Guerriero, F.; Laporte, G. Drone-aided routing: A literature review. Transp. Res. Part C Emerg. Technol. 2020, 120, 102762. [CrossRef]

10. Australian Department of Industry Science Energy and Resources 'Green' Vehicles Definition. Available online: https://www. energy.gov.au/households/transport\#toc-anchor-green-vehicles (accessed on 17 July 2020).

11. Hu, W.; Dong, J.; Hwang, B.; Ren, R.; Chen, Z. A Scientometrics Review on City Logistics Literature: Research Trends, Advanced Theory and Practice. Sustainability 2019, 11, 2724. [CrossRef]

12. Ren, R.; Hu, W.; Dong, J.; Sun, B.; Chen, Y.; Chen, Z. A Systematic Literature Review of Green and Sustainable Logistics: Bibliometric Analysis, Research Trend and Knowledge Taxonomy. Int. J. Environ. Res. Public Health 2019, 17, 261. [CrossRef]

13. Olsson, J.; Hellström, D.; Pålsson, H. Framework of Last Mile Logistics Research: A Systematic Review of the Literature. Sustainability 2019, 11, 7131. [CrossRef]

14. Ranieri, L.; Digiesi, S.; Silvestri, B.; Roccotelli, M. A review of last mile logistics innovations in an externalities cost reduction vision. Sustainability 2018, 10, 782. [CrossRef]

15. Melacini, M.; Perotti, S.; Rasini, M.; Tappia, E. E-fulfilment and distribution in omni-channel retailing: A systematic literature review. Int. J. Phys. Distrib. Logist. Manag. 2018, 48, 391-414. [CrossRef]

16. Lim, S.F.W.T.; Jin, X.; Srai, J.S. Consumer-driven e-commerce. Int. J. Phys. Distrib. Logist. Manag. 2018, 48, 308-332. [CrossRef]

17. de Oliveira, C.M.; De Mello Bandeira, R.A.; Goes, G.V.; Gonçalves, D.N.S.; De Almeida D'Agosto, M. Sustainable vehiclesbased alternatives in last mile distribution of urban freight transport: A Systematic literature review. Sustainability 2017, 9, 324. [CrossRef]

18. Lagorio, A.; Pinto, R.; Golini, R. Research in urban logistics: A systematic literature review. Int. J. Phys. Distrib. Logist. Manag. 2016, 46, 908-931. [CrossRef]

19. Dolati Neghabadi, P.; Evrard Samuel, K.; Espinouse, M.L. Systematic literature review on city logistics: Overview, classification and analysis. Int. J. Prod. Res. 2019, 57, 865-887. [CrossRef]

20. Nenni, M.E.; Sforza, A.; Sterle, C. Sustainability-based review of urban freight models. Soft Comput. 2019, 23, $2899-2909$. [CrossRef]

21. Pelletier, S.; Jabali, O.; Laporte, G. 50th Anniversary Invited Article-Goods Distribution with Electric Vehicles: Review and Research Perspectives. Transp. Sci. 2016, 50, 3-22. [CrossRef]

22. Hilmola, O.-P. Supply Chain Cases; Springer International Publishing: Cham, Switzerland, 2018; ISBN 978-3-319-71657-2.

23. Cattaruzza, D.; Absi, N.; Feillet, D.; González-Feliu, J. Vehicle routing problems for city logistics. EURO J. Transp. Logist. 2017, 6, 51-79. [CrossRef]

24. Cavadas, J.; de Almeida Correia, G.H.; Gouveia, J. A MIP model for locating slow-charging stations for electric vehicles in urban areas accounting for driver tours. Transp. Res. Part E Logist. Transp. Rev. 2015, 75, 188-201. [CrossRef]

25. Deflorio, F.; Castello, L. Dynamic charging-while-driving systems for freight delivery services with electric vehicles: Traffic and energy modelling. Transp. Res. Part C Emerg. Technol. 2017, 81, 342-362. [CrossRef]

26. Pinto, R.; Zambetti, M.; Lagorio, A.; Pirola, F. A network design model for a meal delivery service using drones. Int. J. Logist. Res. Appl. 2020, 23, 354-374. [CrossRef]

27. Cortés-Murcia, D.L.; Prodhon, C.; Murat Afsar, H. The electric vehicle routing problem with time windows, partial recharges and satellite customers. Transp. Res. Part E Logist. Transp. Rev. 2019, 130, 184-206. [CrossRef]

28. Patella, S.M.; Scrucca, F.; Asdrubali, F.; Carrese, S. Carbon Footprint of autonomous vehicles at the urban mobility system level: A traffic simulation-based approach. Transp. Res. Part D Transp. Environ. 2019, 74, 189-200. [CrossRef] 
29. Yu, J.J.Q. Two-stage request scheduling for autonomous vehicle logistic system. IEEE Trans. Intell. Transp. Syst. 2019, 20, 1917-1929. [CrossRef]

30. Bucsky, P. Autonomous vehicles and freight traffic: Towards better efficiency of road, rail or urban logistics? Urban Dev. Issues 2018, 58, 41-52. [CrossRef]

31. Boysen, N.; Briskorn, D.; Fedtke, S.; Schwerdfeger, S. Drone delivery from trucks: Drone scheduling for given truck routes. Networks 2018, 72, 506-527. [CrossRef]

32. Ha, Q.M.; Deville, Y.; Pham, Q.D.; Hà, M.H. On the min-cost Traveling Salesman Problem with Drone. Transp. Res. Part C Emerg. Technol. 2018, 86, 597-621. [CrossRef]

33. Marinelli, M.; Caggiani, L.; Ottomanelli, M.; Dell'Orco, M. En route truck-drone parcel delivery for optimal vehicle routing strategies. IET Intell. Transp. Syst. 2018, 12, 253-261. [CrossRef]

34. Wang, Z.; Sheu, J.B. Vehicle routing problem with drones. Transp. Res. Part B Methodol. 2019, 122, 350-364. [CrossRef]

35. Dorling, K.; Heinrichs, J.; Messier, G.G.; Magierowski, S. Vehicle Routing Problems for Drone Delivery. IEEE Trans. Syst. Man Cybern. Syst. 2017, 47, 70-85. [CrossRef]

36. Shavarani, S.M.; Nejad, M.G.; Rismanchian, F.; Izbirak, G. Application of hierarchical facility location problem for optimization of a drone delivery system: A case study of Amazon prime air in the city of San Francisco. Int. J. Adv. Manuf. Technol. 2018, 95, 3141-3153. [CrossRef]

37. Shavarani, S.M.; Mosallaeipour, S.; Golabi, M.; İzbirak, G. A congested capacitated multi-level fuzzy facility location problem: An efficient drone delivery system. Comput. Oper. Res. 2019, 108, 57-68. [CrossRef]

38. Moghdani, R.; Salimifard, K.; Demir, E.; Benyettou, A. The green vehicle routing problem: A systematic literature review. J. Clean. Prod. 2021, 279, 123691. [CrossRef]

39. Ferreira, J.C.; Steiner, M.T.A.; Canciglieri Junior, O. Multi-objective optimization for the green vehicle routing problem: A systematic literature review and future directions. Cogent Eng. 2020, 7. [CrossRef]

40. Gatta, V.; Marcucci, E.; Delle Site, P.; Le Pira, M.; Carrocci, C.S. Planning with stakeholders: Analysing alternative off-hour delivery solutions via an interactive multi-criteria approach. Res. Transp. Econ. 2019, 73, 53-62. [CrossRef]

41. Le Pira, M.; Marcucci, E.; Gatta, V.; Inturri, G.; Ignaccolo, M.; Pluchino, A. Integrating discrete choice models and agent-based models for ex-ante evaluation of stakeholder policy acceptability in urban freight transport. Res. Transp. Econ. 2017, 64, 13-25. [CrossRef]

42. Gatta, V.; Marcucci, E.; Le Pira, M. Smart urban freight planning process: Integrating desk, living lab and modelling approaches in decision-making. Eur. Transp. Res. Rev. 2017, 9, 32. [CrossRef]

43. Marcucci, E.; Gatta, V.; Marciani, M.; Cossu, P. Measuring the effects of an urban freight policy package defined via a collaborative governance model. Res. Transp. Econ. 2017, 65, 3-9. [CrossRef]

44. Ville, S.; Gonzalez-Feliu, J.; Dablanc, L. The Limits of Public Policy Intervention in Urban Logistics: Lessons from Vicenza (Italy). Eur. Plan. Stud. 2013, 21, 1528-1541. [CrossRef]

45. Cleophas, C.; Cottrill, C.; Ehmke, J.F.; Tierney, K. Collaborative urban transportation: Recent advances in theory and practice. Eur. J. Oper. Res. 2019, 273, 801-816. [CrossRef]

46. Allen, J.; Bektaş, T.; Cherrett, T.; Friday, A.; McLeod, F.; Piecyk, M.; Piotrowska, M.; Zaltz Austwick, M. Enabling a freight traffic controller for collaborative multidrop urban logistics: Practical and theoretical challenges. Transp. Res. Rec. 2017, 2609, 77-84. [CrossRef]

47. Savelsbergh, M.; Van Woensel, T. City logistics: Challenges and opportunities. Transp. Sci. 2016, 50, 579-590. [CrossRef]

48. Ducret, R. Parcel deliveries and urban logistics: Changes and challenges in the courier express and parcel sector in Europe-The French case. Res. Transp. Bus. Manag. 2014, 11, 15-22. [CrossRef]

49. Schöder, D.; Ding, F.; Campos, J.K. The Impact of E-Commerce Development on Urban Logistics Sustainability. Open J. Soc. Sci. 2016, 4, 1-6. [CrossRef]

50. de Mello Bandeira, R.A.; Goes, G.V.; Schmitz Gonçalves, D.N.; D'Agosto, M. de A.; Oliveira, C.M. de Electric vehicles in the last mile of urban freight transportation: A sustainability assessment of postal deliveries in Rio de Janeiro-Brazil. Transp. Res. Part D Transp. Environ. 2019, 67, 491-502. [CrossRef]

51. Lebeau, P.; De Cauwer, C.; Van Mierlo, J.; Macharis, C.; Verbeke, W.; Coosemans, T. Conventional, Hybrid, or Electric Vehicles: Which Technology for an Urban Distribution Centre? Sci. World J. 2015, 2015. [CrossRef]

52. Browne, M.; Allen, J.; Leonardi, J. Evaluating the use of an urban consolidation centre and electric vehicles in central London. IATSS Res. 2011, 35, 1-6. [CrossRef]

53. Faccio, M.; Gamberi, M. New city logistics paradigm: From the "Last Mile" to the "Last 50 Miles" sustainable distribution. Sustainability 2015, 7, 14873-14894. [CrossRef]

54. Boerkamps, J.H.K.; Van Binsbergen, A.J.; Bovy, P.H.L. Modeling behavioral aspects of urban freight movement in supply chains. Transp. Res. Rec. 2000, 17-25. [CrossRef]

55. Simoni, M.D.; Marcucci, E.; Gatta, V.; Claudel, C.G. Potential last-mile impacts of crowdshipping services: A simulation-based evaluation. Transportation 2020, 47, 1933-1954. [CrossRef]

56. Gatta, V.; Marcucci, E.; Nigro, M.; Patella, S.; Serafini, S. Public Transport-Based Crowdshipping for Sustainable City Logistics: Assessing Economic and Environmental Impacts. Sustainability 2018, 11, 145. [CrossRef] 
57. Duarte, G.; Rolim, C.; Baptista, P. How battery electric vehicles can contribute to sustainable urban logistics: A real-world application in Lisbon, Portugal. Sustain. Energy Technol. Assessments 2016, 15, 71-78. [CrossRef]

58. Giordano, A.; Fischbeck, P.; Matthews, H.S. Environmental and economic comparison of diesel and battery electric delivery vans to inform city logistics fleet replacement strategies. Transp. Res. Part D Transp. Environ. 2018, 64, 216-229. [CrossRef]

59. Figliozzi, M.A. Lifecycle modeling and assessment of unmanned aerial vehicles (Drones) CO2e emissions. Transp. Res. Part D Transp. Environ. 2017, 57, 251-261. [CrossRef]

60. Figliozzi, M.; Saenz, J.; Faulin, J. Minimization of urban freight distribution lifecycle CO2e emissions: Results from an optimization model and a real-world case study. Transp. Policy 2020, 86, 60-68. [CrossRef]

61. Stolaroff, J.K.; Samaras, C.; O’Neill, E.R.; Lubers, A.; Mitchell, A.S.; Ceperley, D. Energy use and life cycle greenhouse gas emissions of drones for commercial package delivery. Nat. Commun. 2018, 9, 1-13. [CrossRef]

62. Taefi, T.T.; Stütz, S.; Fink, A. Assessing the cost-optimal mileage of medium-duty electric vehicles with a numeric simulation approach. Transp. Res. Part D Transp. Environ. 2017, 56, 271-285. [CrossRef]

63. Taefi, T.T. Viability of electric vehicles in combined day and night delivery: A total cost of ownership example in Germany. Eur. J. Transp. Infrastruct. Res. 2016, 16, 512-553. [CrossRef]

64. Patella, S.M.; Scrucca, F.; Asdrubali, F.; Carrese, S. Traffic Simulation-Based Approach for A Cradle-to-Grave Greenhouse Gases Emission Model. Sustainability 2019, 11, 4328. [CrossRef]

65. Muñoz-Villamizar, A.; Quintero-Araújo, C.L.; Montoya-Torres, J.R.; Faulin, J. Short- and mid-term evaluation of the use of electric vehicles in urban freight transport collaborative networks: A case study. Int. J. Logist. Res. Appl. 2019, 22, 229-252. [CrossRef]

66. Muñoz-Villamizar, A.; Montoya-Torres, J.R.; Faulin, J. Impact of the use of electric vehicles in collaborative urban transport networks: A case study. Transp. Res. Part D Transp. Environ. 2017, 50, 40-54. [CrossRef]

67. Wang, J.; Lim, M.K.; Tseng, M.L.; Yang, Y. Promoting low carbon agenda in the urban logistics network distribution system. J. Clean. Prod. 2019, 211, 146-160. [CrossRef]

68. Melo, S.; Baptista, P. Evaluating the impacts of using cargo cycles on urban logistics: Integrating traffic, environmental and operational boundaries. Eur. Transp. Res. Rev. 2017, 9. [CrossRef]

69. Allen, J.; Piecyk, M.; Piotrowska, M.; McLeod, F.; Cherrett, T.; Ghali, K.; Nguyen, T.; Bektas, T.; Bates, O.; Friday, A.; et al. Understanding the impact of e-commerce on last-mile light goods vehicle activity in urban areas: The case of London. Transp. Res. Part D Transp. Environ. 2018, 61, 325-338. [CrossRef]

70. Browne, M.; Allen, J.; Nemoto, T.; Patier, D.; Visser, J. Reducing Social and Environmental Impacts of Urban Freight Transport: A Review of Some Major Cities. Procedia Soc. Behav. Sci. 2012, 39, 19-33. [CrossRef]

71. Vleugel, J.M.; Bal, F. More space and improved living conditions in cities with autonomous vehicles. Int. J. Des. Nat. Ecodynamics 2018, 12, 505-515. [CrossRef]

72. Koiwanit, J. Analysis of environmental impacts of drone delivery on an online shopping system. Adv. Clim. Chang. Res. 2018, 9, 201-207. [CrossRef]

73. Brown, J.R.; Guiffrida, A.L. Carbon emissions comparison of last mile delivery versus customer pickup. Int. J. Logist. Res. Appl. 2014, 17, 503-521. [CrossRef]

74. Weber, C.L.; Hendrickson, C.T.; Matthews, H.S.; Nagengast, A.; Nealer, R.; Jaramillo, P. Life cycle comparison of traditional retail and e-commerce logistics for electronic products: A case study of buy.com. In Proceedings of the 2009 IEEE International Symposium on Sustainable Systems and Technology, Phoenix, AZ, USA, 18-20 May 2009; IEEE: Piscataway, NJ, USA, 2009; pp. 1-6.

75. De Marco, A.; Mangano, G.; Zenezini, G. Classification and benchmark of City Logistics measures: An empirical analysis. Int. J. Logist. Res. Appl. 2018, 21, 1-19. [CrossRef]

76. Taniguchi, E.; Thompson, R.G.; Yamada, T. Predicting the effects of city logistics schemes. Transp. Rev. 2003, 23, 489-515. [CrossRef]

77. Goodchild, A.; Toy, J. Delivery by drone: An evaluation of unmanned aerial vehicle technology in reducing $\mathrm{CO}_{2}$ emissions in the delivery service industry. Transp. Res. Part D Transp. Environ. 2018, 61, 58-67. [CrossRef]

78. Crainic, T.G.; Ricciardi, N.; Storchi, G. Models for evaluating and planning city logistics systems. Transp. Sci. 2009, 43, 432-454. [CrossRef]

79. Crainic, T.G.; Ricciardi, N.; Storchi, G. Advanced freight transportation systems for congested urban areas. Transp. Res. Part C Emerg. Technol. 2004, 12, 119-137. [CrossRef]

80. Murray, C.C.; Chu, A.G. The flying sidekick traveling salesman problem: Optimization of drone-assisted parcel delivery. Transp. Res. Part C Emerg. Technol. 2015, 54, 86-109. [CrossRef]

81. Ropke, S.; Cordeau, J.F. Branch and cut and price for the pickup and delivery problem with time windows. Transp. Sci. 2009, 43, 267-286. [CrossRef]

82. Taniguchi, E.; Van Der Heijden, R.E.C.M. An evaluation methodology for city logistics. Transp. Rev. 2000, 20, 65-90. [CrossRef]

83. Boyer, K.K.; Prud'homme, A.M.; Chung, W. the Last Mile Challenge: Evaluating the Effects of Customer Density and Delivery Window Patterns. J. Bus. Logist. 2009, 30, 185-201. [CrossRef]

84. Ćirović, G.; Pamučar, D.; Božanić, D. Green logistic vehicle routing problem: Routing light delivery vehicles in urban areas using a neuro-fuzzy model. Expert Syst. Appl. 2014, 41, 4245-4258. [CrossRef] 
85. Motraghi, A.; Marinov, M.V. Analysis of urban freight by rail using event based simulation. Simul. Model. Pract. Theory 2012, 25, 73-89. [CrossRef]

86. Ehmke, J.F.; Meisel, S.; Mattfeld, D.C. Floating car based travel times for city logistics. Transp. Res. Part C Emerg. Technol. 2012, 21, 338-352. [CrossRef]

87. Juan, A.A.; Mendez, C.A.; Faulin, J.; De Armas, J.; Grasman, S.E. Electric vehicles in logistics and transportation: A survey on emerging environmental, strategic, and operational challenges. Energies 2016, 9, 86. [CrossRef]

88. Fatnassi, E.; Chaouachi, J.; Klibi, W. Planning and operating a shared goods and passengers on-demand rapid transit system for sustainable city-logistics. Transp. Res. Part B Methodol. 2015, 81, 440-460. [CrossRef]

89. Devari, A.; Nikolaev, A.G.; He, Q. Crowdsourcing the last mile delivery of online orders by exploiting the social networks of retail store customers. Transp. Res. Part E Logist. Transp. Rev. 2017, 105, 105-122. [CrossRef]

90. Gentile, G.; Vigo, D. Movement generation and trip distribution for freight demand modelling applied to city logistics. Eur. Transp. Trasp. Eur. 2013, 1-27.

91. Zhou, L.; Baldacci, R.; Vigo, D.; Wang, X. A Multi-Depot Two-Echelon Vehicle Routing Problem with Delivery Options Arising in the Last Mile Distribution. Eur. J. Oper. Res. 2018, 265, 765-778. [CrossRef]

92. McLeod, F.; Cherrett, T. Loading bay booking and control for urban freight. Int. J. Logist. Res. Appl. 2011, 14, 385-397. [CrossRef]

93. Ham, A.M. Integrated scheduling of m-truck, m-drone, and m-depot constrained by time-window, drop-pickup, and m-visit using constraint programming. Transp. Res. Part C Emerg. Technol. 2018, 91, 1-14. [CrossRef]

94. Deutsch, Y.; Golany, B. A parcel locker network as a solution to the logistics last mile problem. Int. J. Prod. Res. 2018, 56, 251-261. [CrossRef]

95. Park, H.; Park, D.; Jeong, I.J. An effects analysis of logistics collaboration in last-mile networks for CEP delivery services. Transp. Policy 2016, 50, 115-125. [CrossRef]

96. Boysen, N.; Schwerdfeger, S.; Weidinger, F. Scheduling last-mile deliveries with truck-based autonomous robots. Eur. J. Oper. Res. 2018, 271, 1085-1099. [CrossRef]

97. Tavana, M.; Khalili-Damghani, K.; Santos-Arteaga, F.J.; Zandi, M.H. Drone shipping versus truck delivery in a cross-docking system with multiple fleets and products. Expert Syst. Appl. 2017, 72, 93-107. [CrossRef]

98. Schiffer, M.; Walthera, G. An adaptive large neighborhood search for the location-routing problem with intra-route facilities. Transp. Sci. 2018, 52, 331-352. [CrossRef]

99. Yu, J.J.Q.; Lam, A.Y.S. Autonomous Vehicle Logistic System: Joint Routing and Charging Strategy. IEEE Trans. Intell. Transp. Syst. 2018, 19, 2175-2187. [CrossRef]

100. Pamučar, D.; Gigović, L.; Ćirović, G.; Regodić, M. Transport spatial model for the definition of green routes for city logistics centers. Environ. Impact Assess. Rev. 2016, 56, 72-87. [CrossRef]

101. Jie, W.; Yang, J.; Zhang, M.; Huang, Y. The two-echelon capacitated electric vehicle routing problem with battery swapping stations: Formulation and efficient methodology. Eur. J. Oper. Res. 2019, 272, 879-904. [CrossRef]

102. Behiri, W.; Belmokhtar-Berraf, S.; Chu, C. Urban freight transport using passenger rail network: Scientific issues and quantitative analysis. Transp. Res. Part E Logist. Transp. Rev. 2018, 115, 227-245. [CrossRef]

103. Chiang, W.C.; Li, Y.; Shang, J.; Urban, T.L. Impact of drone delivery on sustainability and cost: Realizing the UAV potential through vehicle routing optimization. Appl. Energy 2019, 242, 1164-1175. [CrossRef]

104. Pelletier, S.; Jabali, O.; Laporte, G. Charge scheduling for electric freight vehicles. Transp. Res. Part B Methodol. 2018, 115, 246-269. [CrossRef]

105. Battini, D.; Peretti, U.; Persona, A.; Sgarbossa, F. Application of humanitarian last mile distribution model. J. Humanit. Logist. Supply Chain Manag. 2014, 4, 131-148. [CrossRef]

106. Behnke, M.; Kirschstein, T. The impact of path selection on GHG emissions in city logistics. Transp. Res. Part E Logist. Transp. Rev. 2017, 106, 320-336. [CrossRef]

107. Ahani, P.; Arantes, A.; Melo, S. A portfolio approach for optimal fleet replacement toward sustainable urban freight transportation. Transp. Res. Part D Transp. Environ. 2016, 48, 357-368. [CrossRef]

108. Mbiadou Saleu, R.G.; Deroussi, L.; Feillet, D.; Grangeon, N.; Quilliot, A. An iterative two-step heuristic for the parallel drone scheduling traveling salesman problem. Networks 2018, 72, 459-474. [CrossRef]

109. Baldi, M.M.; Manerba, D.; Perboli, G.; Tadei, R. A Generalized Bin Packing Problem for parcel delivery in last-mile logistics. Eur. J. Oper. Res. 2019, 274, 990-999. [CrossRef]

110. Kin, B.; Spoor, J.; Verlinde, S.; Macharis, C.; Van Woensel, T. Modelling alternative distribution set-ups for fragmented last mile transport: Towards more efficient and sustainable urban freight transport. Case Stud. Transp. Policy 2018, 6, 125-132. [CrossRef]

111. Franceschetti, A.; Honhon, D.; Laporte, G.; Van Woensel, T.; Fransoo, J.C. Strategic fleet planning for city logistics. Transp. Res. Part B Methodol. 2017, 95, 19-40. [CrossRef]

112. Sopha, B.M.; Siagian, A.; Asih, A.M.S. Simulating Dynamic Vehicle Routing Problem using Agent-Based Modeling and Simulation. IEEE Int. Conf. Ind. Eng. Eng. Manag. 2016, 1335-1339. [CrossRef]

113. Wang, F.; Wang, F.; Ma, X.; Liu, J. Demystifying the Crowd Intelligence in Last Mile Parcel Delivery for Smart Cities. IEEE Netw. 2019, 33, 23-29. [CrossRef]

114. Firdausiyah, N.; Taniguchi, E.; Qureshi, A.G. Modeling city logistics using adaptive dynamic programming based multi-agent simulation. Transp. Res. Part E Logist. Transp. Rev. 2019, 125, 74-96. [CrossRef] 
115. Karak, A.; Abdelghany, K. The hybrid vehicle-drone routing problem for pick-up and delivery services. Transp. Res. Part $C$ Emerg. Technol. 2019, 102, 427-449. [CrossRef]

116. Pelletier, S.; Jabali, O.; Laporte, G. The electric vehicle routing problem with energy consumption uncertainty. Transp. Res. Part B Methodol. 2019, 126, 225-255. [CrossRef]

117. Troudi, A.; Addouche, S.A.; Dellagi, S.; El Mhamedi, A. Sizing of the drone delivery fleet considering energy autonomy. Sustainability 2018, 10, 344. [CrossRef]

118. Rezgui, D.; Chaouachi Siala, J.; Aggoune-Mtalaa, W.; Bouziri, H. Application of a variable neighborhood search algorithm to a fleet size and mix vehicle routing problem with electric modular vehicles. Comput. Ind. Eng. 2019, 130, 537-550. [CrossRef]

119. Scherr, Y.O.; Neumann Saavedra, B.A.; Hewitt, M.; Mattfeld, D.C. Service network design with mixed autonomous fleets. Transp. Res. Part E Logist. Transp. Rev. 2019, 124, 40-55. [CrossRef]

120. Bergqvist, R.; Monios, J. The last mile, inbound logistics and intermodal high capacity transport-The case of Jula in Sweden. World Rev. Intermodal Transp. Res. 2016, 6, 74. [CrossRef]

121. Li, Y.; Lim, M.K.; Tan, Y.; Lee, S.Y.; Tseng, M.L. Sharing economy to improve routing for urban logistics distribution using electric vehicles. Resour. Conserv. Recycl. 2020, 153, 104585. [CrossRef]

122. Moeini, M.; Salewski, H. A Genetic Algorithm for Solving the Truck-Drone-ATV Routing Problem. In Optimization of Complex Systems: Theory, Models, Algorithms and Applications; Springer: Berlin/Heidelberg, Germany, 2020; pp. $1023-1032$.

123. Li, H.; Liu, Y.; Chen, K.; Lin, Q. The two-echelon city logistics system with on-street satellites. Comput. Ind. Eng. 2020, $139,105577$. [CrossRef]

124. Fikar, C.; Hirsch, P.; Gronalt, M. A decision support system to investigate dynamic last-mile distribution facilitating cargo-bikes. Int. J. Logist. Res. Appl. 2018, 21, 300-317. [CrossRef]

125. Chen, B. Location Selection of Logistics Center in e-Commerce Network Environments. Am. J. Neural Networks Appl. 2017, 3, 40. [CrossRef]

126. Ehmke, J.F.; Mattfeld, D.C. Data Allocation and Application for Time-Dependent Delivery in Urban Areas. In Proceedings of the 12th World Conference on Transport Research, Lisbon, Portugal, 11-15 July 2010; Volume 46, pp. 1-16.

127. Dekker, R.; Bloemhof, J.; Mallidis, I. Operations Research for green logistics-An overview of aspects, issues, contributions and challenges. Eur. J. Oper. Res. 2012, 219, 671-679. [CrossRef]

128. Behrends, S.; Lindholm, M.; Woxenius, J. The impact of urban freight transport: A definition of sustainability from an actor's perspective. Transp. Plan. Technol. 2008, 31, 693-713. [CrossRef]

129. Arvidsson, N. The milk run revisited: A load factor paradox with economic and environmental implications for urban freight transport. Transp. Res. Part A Policy Pract. 2013, 51, 56-62. [CrossRef]

130. Russo, F.; Comi, A. Urban freight transport planning towards green goals: Synthetic environmental evidence from tested results. Sustainability 2016, 8, 381. [CrossRef]

131. Aditjandra, P.T.; Galatioto, F.; Bell, M.C.; Zunder, T.H. Evaluating the impacts of urban freight traffic: Application of microsimulation at a large establishment. Eur. J. Transp. Infrastruct. Res. 2016, 16, 4-22. [CrossRef]

132. Lebeau, P.; Macharis, C.; Van Mierlo, J.; Lebeau, K. Electrifying light commercial vehicles for city logistics? A total cost of ownership analysis. Eur. J. Transp. Infrastruct. Res. 2015, 15, 551-569. [CrossRef]

133. Park, J.; Kim, S.; Suh, K. A comparative analysis of the environmental benefits of drone-based delivery services in urban and rural areas. Sustainability 2018, 10, 888. [CrossRef]

134. Durand, B.; Mahjoub, S.; Senkel, M.P. Delivering to urban online shoppers: The gains from "last-mile" pooling. Supply Chain Forum 2013, 14, 22-31. [CrossRef]

135. Aurambout, J.P.; Gkoumas, K.; Ciuffo, B. Last mile delivery by drones: An estimation of viable market potential and access to citizens across European cities. Eur. Transp. Res. Rev. 2019, 11. [CrossRef]

136. Teoh, T.; Kunze, O.; Teo, C.C.; Wong, Y.D. Decarbonisation of urban freight transport using electric vehicles and opportunity charging. Sustainability 2018, 10, 3258. [CrossRef]

137. Semanjski, I.; Gautama, S. A collaborative stakeholder decision-making approach for sustainable urban logistics. Sustainability 2019, 11, 234. [CrossRef]

138. Digiesi, S.; Fanti, M.P.; Mummolo, G.; Silvestri, B. Externalities reduction strategies in last mile logistics: A review. In Proceedings of the 2017 IEEE International Conference on Service Operations and Logistics, and Informatics (SOLI), Bari, Italy, 18-20 September 2017; pp. 248-253. [CrossRef]

139. Lebeau, P.; Macharis, C.; Mierlo, J. Van How to improve the total cost of ownership of electric vehicles: An analysis of the light commercial vehicle segment. World Electr. Veh. J. 2019, 10, 90. [CrossRef]

140. Marmiroli, B.; Venditti, M.; Dotelli, G.; Spessa, E. The transport of goods in the urban environment: A comparative life cycle assessment of electric, compressed natural gas and diesel light-duty vehicles. Appl. Energy 2020, 260, 114236. [CrossRef]

141. Cárdenas, I.; Beckers, J.; Vanelslander, T. E-commerce last-mile in Belgium: Developing an external cost delivery index. Res. Transp. Bus. Manag. 2017, 24, 123-129. [CrossRef]

142. Moore, A.M. Innovative scenarios for modeling intra-city freight delivery. Transp. Res. Interdiscip. Perspect. $2019,3,100024$. [CrossRef]

143. Fagnant, D.J.; Kockelman, K. Preparing a nation for autonomous vehicles: Opportunities, barriers and policy recommendations. Transp. Res. Part A Policy Pract. 2015, 77, 167-181. [CrossRef] 
144. Cherrett, T.; Allen, J.; McLeod, F.; Maynard, S.; Hickford, A.; Browne, M. Understanding urban freight activity—Key issues for freight planning. J. Transp. Geogr. 2012, 24, 22-32. [CrossRef]

145. Lindholm, M.; Behrends, S. Challenges in urban freight transport planning-A review in the Baltic Sea Region. J. Transp. Geogr. 2012, 22, 129-136. [CrossRef]

146. Tadić, S.; Zečević, S.; Krstić, M. A novel hybrid MCDM model based on fuzzy DEMATEL, fuzzy ANP and fuzzy VIKOR for city logistics concept selection. Expert Syst. Appl. 2014, 41, 8112-8128. [CrossRef]

147. Schliwa, G.; Armitage, R.; Aziz, S.; Evans, J.; Rhoades, J. Sustainable city logistics—Making cargo cycles viable for urban freight transport. Res. Transp. Bus. Manag. 2015, 15, 50-57. [CrossRef]

148. Marcucci, E.; Danielis, R. The potential demand for a urban freight consolidation centre. Transportation (Amst). 2008, 35, 269-284. [CrossRef]

149. Ballantyne, E.E.F.; Lindholm, M.; Whiteing, A. A comparative study of urban freight transport planning: Addressing stakeholder needs. J. Transp. Geogr. 2013, 32, 93-101. [CrossRef]

150. Guerra, E. Planning for Cars That Drive Themselves: Metropolitan Planning Organizations, Regional Transportation Plans, and Autonomous Vehicles. J. Plan. Educ. Res. 2016, 36, 210-224. [CrossRef]

151. Muñuzuri, J.; Cortés, P.; Guadix, J.; Onieva, L. City logistics in Spain: Why it might never work. Cities 2012, 29, 133-141. [CrossRef]

152. Gruber, J.; Kihm, A.; Lenz, B. A new vehicle for urban freight? An ex-ante evaluation of electric cargo bikes in courier services. Res. Transp. Bus. Manag. 2014, 11, 53-62. [CrossRef]

153. Russo, F.; Comi, A. A model system for the ex-ante assessment of city logistics measures. Res. Transp. Econ. 2011, 31, 81-87. [CrossRef]

154. Morganti, E.; Gonzalez-Feliu, J. City logistics for perishable products. The case of the Parma's Food Hub. Case Stud. Transp. Policy 2015, 3, 120-128. [CrossRef]

155. Ajanovic, A.; Haas, R. Dissemination of electric vehicles in urban areas: Major factors for success. Energy 2016, 115, 1451-1458. [CrossRef]

156. Lenz, B.; Riehle, E. Bikes for urban freight? Transp. Res. Rec. 2013, 39-45. [CrossRef]

157. Roumboutsos, A.; Kapros, S.; Vanelslander, T. Green city logistics: Systems of Innovation to assess the potential of E-vehicles. Res. Transp. Bus. Manag. 2014, 11, 43-52. [CrossRef]

158. Taefi, T.T.; Kreutzfeldt, J.; Held, T.; Fink, A. Supporting the adoption of electric vehicles in urban road freight transport-A multicriteria analysis of policy measures in Germany. Transp. Res. Part A Policy Pract. 2016, 91, 61-79. [CrossRef]

159. Anand, N.; van Duin, R.; Tavasszy, L. Ontology-based multi-agent system for urban freight transportation. Int. J. Urban Sci. 2014, 18, 133-153. [CrossRef]

160. Nuzzolo, A.; Comi, A.; Ibeas, A.; Moura, J.L. Urban freight transport and city logistics policies: Indications from Rome, Barcelona, and Santander. Int. J. Sustain. Transp. 2016, 10, 552-566. [CrossRef]

161. Bjerkan, K.Y.; Sund, A.B.; Nordtømme, M.E. Stakeholder responses to measures green and efficient urban freight. Res. Transp. Bus. Manag. 2014, 11, 32-42. [CrossRef]

162. Yuen, K.F.; Wang, X.; Ng, L.T.W.; Wong, Y.D. An investigation of customers' intention to use self-collection services for last-mile delivery. Transp. Policy 2018, 66, 1-8. [CrossRef]

163. Lebeau, P.; Macharis, C.; Van Mierlo, J. Exploring the choice of battery electric vehicles in city logistics: A conjoint-based choice analysis. Transp. Res. Part E Logist. Transp. Rev. 2016, 91, 245-258. [CrossRef]

164. Harrington, T.S.; Singhai, J.; Kumar, M.; Wohlrab, J. Identifying design criteria for urban system last-mile solutions -A multistakeholder perspective. Prod. Plan. Control 2016, 27, 456-476. [CrossRef]

165. Jaller, M.; Wang, X.C.; Holguín-Veras, J. Large urban freight traffic generators: Opportunities for city logistics initiatives. J. Transp. Land Use 2015, 8, 51-67. [CrossRef]

166. Morganti, E.; Browne, M. Technical and operational obstacles to the adoption of electric vans in France and the UK: An operator perspective. Transp. Policy 2018, 63, 90-97. [CrossRef]

167. Mirhedayatian, S.M.; Yan, S. A framework to evaluate policy options for supporting electric vehicles in urban freight transport. Transp. Res. Part D Transp. Environ. 2018, 58, 22-38. [CrossRef]

168. Kane, M.; Whitehead, J. How to ride transport disruption -a sustainable framework for future urban mobility. Aust. Plan. 2017, 54, 177-185. [CrossRef]

169. Musolino, G.; Rindone, C.; Polimeni, A.; Vitetta, A. Planning urban distribution center location with variable restocking demand scenarios: General methodology and testing in a medium-size town. Transp. Policy 2019, 80, 157-166. [CrossRef]

170. Arvidsson, N.; Givoni, M.; Woxenius, J. Exploring last mile synergies in passenger and freight transport. Built Environ. 2016, 42, 523-538. [CrossRef]

171. Hopkins, D.; McCarthy, A. Change trends in urban freight delivery: A qualitative inquiry. Geoforum 2016, 74, 158-170. [CrossRef]

172. Hoffmann, T.; Prause, G. On the regulatory framework for last-mile delivery robots. Machines 2018, 6, 33. [CrossRef]

173. Cagliano, A.C.; Carlin, A.; Mangano, G.; Rafele, C. Analyzing the diffusion of eco-friendly vans for urban freight distribution. Int. J. Logist. Manag. 2017, 28, 1218-1242. [CrossRef]

174. Lebeau, P.; Macharis, C.; Van Mierlo, J.; Janjevic, M. Improving policy support in city logistics: The contributions of a multi-actor multi-criteria analysis. Case Stud. Transp. Policy 2018, 6, 554-563. [CrossRef] 
175. Christensen, L.; Klauenberg, J.; Kveiborg, O.; Rudolph, C. Suitability of commercial transport for a shift to electric mobility with Denmark and Germany as use cases. Res. Transp. Econ. 2017, 64, 48-60. [CrossRef]

176. Kellermann, R.; Biehle, T.; Fischer, L. Drones for parcel and passenger transportation: A literature review. Transp. Res. Interdiscip. Perspect. 2020, 4, 100088. [CrossRef]

177. Buldeo Rai, H.; Verlinde, S.; Macharis, C. City logistics in an omnichannel environment. The case of Brussels. Case Stud. Transp. Policy 2019, 7, 310-317. [CrossRef]

178. Hu, W.; Dong, J.; Hwang, B.G.; Ren, R.; Chen, Y.; Chen, Z. Using system dynamics to analyze the development of urban freight transportation system based on rail transit: A case study of Beijing. Sustain. Cities Soc. 2020, 53, 101923. [CrossRef]

179. Matusiewicz, M. Towards sustainable urban logistics: Creating sustainable urban freight transport on the example of a Limited Accessibility Zone in Gdansk. Sustainability 2019, 11, 3879. [CrossRef]

180. Skiver, R.L. Crowdserving: A Last Mile Delivery Method for Brick-and-Mortar Retailers. Glob. J. Bus. Res. 2017, 11, 67-77.

181. Arroyo, J.L.; Felipe, Á.; Ortuño, M.T.; Tirado, G. Effectiveness of carbon pricing policies for promoting urban freight electrification: Analysis of last mile delivery in Madrid. Cent. Eur. J. Oper. Res. 2019. [CrossRef]

182. Monios, J.; Bergqvist, R. The transport geography of electric and autonomous vehicles in road freight networks. J. Transp. Geogr. 2019, 80, 102500. [CrossRef]

183. Ehrler, V.C.; Schöder, D.; Seidel, S. Challenges and perspectives for the use of electric vehicles for last mile logistics of grocery e-commerce-Findings from case studies in Germany. Res. Transp. Econ. 2019. [CrossRef]

184. Orving, T.; Fossheim, K.; Andersen, J. Public Sector Facilitation of Cargo Bike Operations to Improve City Logistics; Elsevier Inc.: Amsterdam, The Netherlands, 2019; ISBN 9780128176962.

185. Cheng, G.; Liu, C. Research on business operating model of new energy battery electric vehicles used as urban logistics cars. Int. J. Multimed. Ubiquitous Eng. 2016, 11,387-400. [CrossRef] 